\title{
Synthesis of Azido-Glycans for Chemical Glycomodification of Proteins
}

\author{
Wawryszyn, Mirella
}

2018-08-23

Wawryszyn, M , Sauter , P F , Nieger , M , Koos , M R M , Koehler , C , Luy , B , Lemke , E A \& Bräse , S 2018 , ' Synthesis of Azido-Glycans for Chemical Glycomodification of Proteins ' , European Journal of Organic Chemistry , no. 31 , pp. 4296-4305 . https://doi.org/10.1002/ejoc.20180060

http://hdl.handle.net/10138/324818

https://doi.org/10.1002/ejoc.201800602

unspecified

acceptedVersion

Downloaded from Helda, University of Helsinki institutional repository.

This is an electronic reprint of the original article.

This reprint may differ from the original in pagination and typographic detail.

Please cite the original version. 


\title{
Synthesis of Azido-Glycans for Chemical Glycomodification of Proteins
}

\author{
M. Wawryszyn, ${ }^{\dagger[a, b]}$ P. F. Sauter, ${ }^{\dagger[a]}$ M. Nieger ${ }^{[c]}$ M. R. M. Koos, ${ }^{[d]}$ C. Koehler, ${ }^{[e, f, g]}$ B. Luy, ${ }^{[a, d]}$ \\ E. A. Lemke, ${ }^{[\mathrm{e}, \mathrm{f}, \mathrm{g}]}$ and S. Bräse ${ }^{\star[a, g, h]}$
}

\begin{abstract}
Chemically produced, accurately linkable oligosaccharides are of importance for the synthesis of neo-glycoproteins. On the route to high-mannose type $\mathrm{N}$-glycans, we present a convenient synthesis of several glycans bearing an azide moiety at the reducing end. An azido-glycan core structure as valuable precursor was modified into the protected $\mathrm{N}$-glycan pentasaccharide core structure and the possibility of modular attachment of different antenna was demonstrated through synthesis of a pentamannose donor and glycosylation with the core structure. The azido function allows for chemical ligation with recombinantly modified proteins featuring nonnatural cyclooctyne amino acids, providing access to customized glycopatterns of glycoproteins, e.g., of antibodies that are of high interest for biopharmaceutical applications.
\end{abstract}

\section{Introduction}

Carbohydrates are ubiquitously present in nature and a main constituent of all biomass. ${ }^{[1]}$ Besides their biological importance

[a] Institute of Organic Chemistry, Karlsruhe Institute of Technology (KIT), Fritz-Haber-Weg 6, 76131 Karlsruhe, Germany.

[b] Soft Matter Synthesis Laboratory, Institute for Biological Interfaces 3, Karlsruhe Institute of Technology (KIT), Hermannvon-Helmholtz-Platz 1, 76344 Eggenstein-Leopoldshafen, Germany.

[c] Department of Chemistry, University of Helsinki, P. O. Box 55 00014 University of Helsinki, Finland.

[d] Institute for Biological Interfaces 4, Karlsruhe Institute of Technology (KIT), Hermann-von-Helmholtz-Platz 1, 76344 Eggenstein-Leopoldshafen, Germany.

[e] Departments of Biology and Chemistry, Pharmacy and Geosciences, Johannes Gutenberg-University Mainz, Johannesvon-Mullerweg 6, 55128 Mainz, Germany.

[f] Institute of Molecular Biology (IMB), Ackermannweg 4, 55128 Mainz, Germany.

[g] Structural and Computational Biology Unit \& Cell Biology and Biophysics Unit, European Molecular Biology Laboratory (EMBL), Meyerhofstraße 1, 69117 Heidelberg, Germany.

[h] Institute of Toxicology and Genetics, Karlsruhe Institute of Technology (KIT), Hermann-von-Helmholtz-Platz 1, 76344 Eggenstein-Leopoldshafen, Germany.

$\dagger \quad$ M. W. and P.F. S. contributed equally to this work.

* Correspondence should be addressed to Stefan.Braese@kit.edu, www.ioc.kit.edu/braese/

Electronic Supplementary Information (ESI) available: Supporting Information (SI) see DOI: 10.1039/x0xx00000x. Crystallographic data can be obtained free of charge from The Cambridge Crystallographic Data Centre via www.ccdc.cam.ac.uk/data request/cif: CCDC 1565150 (4a), CCDC 1565151 (6b), CCDC 1565152 (7b), CCDC 1565152 (11c), CCDC 1565154 (19' only shown in the SI). for energy storage and as structural components, they also occur as a part of many important biomolecules where their role is still not completely understood. ${ }^{[2]}$ Oligosaccharides $\mathrm{N}$-linked to proteins via the carboxamide side chain of asparagine - the so called $\mathrm{N}$-glycans - are the most abundant post-translational modification of eukaryotic proteins. ${ }^{[1 b, 3]}$ Naturally occurring $\mathrm{N}$-glycans are categorized into three structural classes: the highmannose, the complex and the hybrid type. ${ }^{[1 b, 4]}$ These $\mathrm{N}$-glycans share a common pentasaccharide core structure, which derives from an evolutionary preserved biosynthetic pathway. ${ }^{[4 b, 5]}$ Modifications beyond this core structure are carried out by a set of glycan processing enzymes that overlap in their localization. Thus, a large variety of different oligosaccharides is formed in a combinatorial manner. ${ }^{[6]}$ Therefore, glycoproteins exist as heterogeneous mixtures of different glycoforms. ${ }^{[7]}$ However, glycosylation plays a central role in secretion, stability, function, and immunogenicity of glycoproteins (GPs) and a detailed understanding of their structure-activity relationship is of pivotal interest. ${ }^{[8]}$ Thus, an easy way to the access of homogeneous glycoforms is required. ${ }^{[8 a, 8 c-e]}$ The impaired isolation of homogeneous glycoforms for biological studies creates an evergrowing need for synthetic $N$-glycans. In contrast, protein design is well understood and even site-specific incorporation of unnatural amino acids (nAAs) is routinely possible since the 1980s and several proteins have been approved for cancer therapy. $\left.{ }^{[8 a}, 8 b, 9\right]$

Multiple syntheses of $\mathrm{N}$-glycans have been established for elucidation of their biological roles. Kerekgyarto et al. reported the synthesis of a benzylated core pentasaccharide glycosyl azide. ${ }^{[10]}$ Several di-, and triantennary $\mathrm{N}$-glycans and respective glycoconjugates were successfully synthesized by Danishefsky et al. ${ }^{[11]}$ The synthesis of a complex type glycan containing a core fucose was reported by Fukase et al. and high-mannose type by Matsuo et al. ${ }^{[12]}$ Unverzagt et al. established syntheses of various $\mathrm{N}$-glycans, including core-fucosylated multiantennary bisected structures. ${ }^{[13]}$ Chemoenzymatic approaches for synthesis of $\mathrm{N}$ glycans were investigated by Ito et al., ${ }^{[14]}$ Wong et al., ${ }^{[15]}$ and Boons et al. ${ }^{[16]}$ A fully automated synthesis of several glycans was reported by Seeberger et al. ${ }^{[17]}$

Without enzymatic treatment, however, a native glycan with a hydroxyl group at the reducing end is neither reactive without harsh chemical conditions, nor does it allow site specific reactions under physiological conditions. ${ }^{[18]}$ To provide strictly homogeneous glycoforms, we propose a biorthogonal approach: Glycans synthesized bearing a suitable moiety at their reducing end are combined with recombinantly modified proteins featuring corresponding nAA. In this way, arbitrary glycans can be created and directed to designated positions in a protein to achieve any 
glycopattern that may be of interest. Azido-functionalized mono-, di-, and oligosaccharides are well known in the literature and can be particularly helpful in a variety of glyco-conjugation reactions, e.g. copper(I)-catalyzed alkyne-azide cycloaddition (CuAAC) click-reaction. ${ }^{[19]} \quad$ Using strain-promoted alkyne-azide cycloaddition (SPAAC) ligation instead, as an example of copperfree click-chemistry, glycoproteins with a defined glycopattern can be obtained as shown in Figure 1 and Scheme 9. ${ }^{[9 f, 20]}$ The ligation protein bears a cyclooctynyl group as an $\mathrm{nAA}$, obtained by genetic code expansion. We established a fast and easy access to three biologically inspired azido-glycans, 1, 2, and 3, via several strategies, outlined in the retrosynthetic approach shown in Figure 2 and explained in the following.

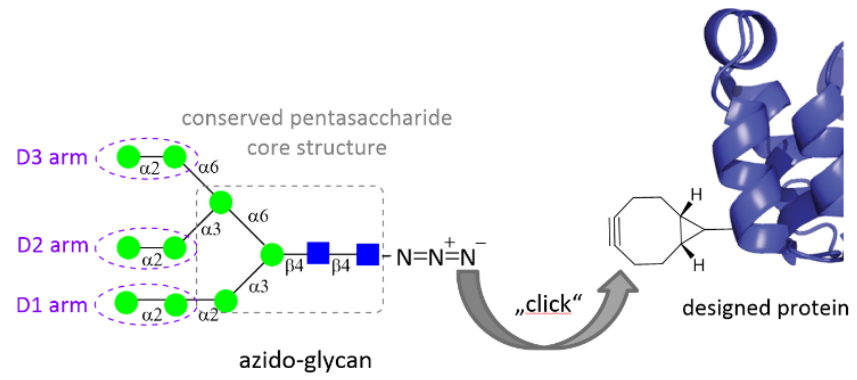

Figure 1. Access to homogeneous glycoproteins: Illustration of an azido-glycan on the left, exemplarily shown with a high-mannose glycopattern, as well as an arbitrary recombinantly modified protein featuring a cyclooctyne nAA. The attachment of glycan to a protein is achieved via strain-promoted azide-alkyne cyclo-addition (SPAAC).

\section{Results and Discussion}

To show a possible way towards neo-glycoproteins which are manufacturable via biorthogonal reactions such as strainpromoted 1,3-dipolar cycloaddition between azide and cyclooctyne derivatives, we synthesized the azido-glycans 1, 2, and 3 shown in Figure 2.

The smallest target structure, 3, represents the unbranched core structure of all $\mathrm{N}$-glycans. The glycopattern of pentamer 2 represents the conserved pentasaccharide core structure, which all naturally occuring $\mathrm{N}$-glycans have in common. The octameric structure $\mathbf{1}$ is close to a typical high-mannose glycopattern, even though in living systems more complex patterns are encountered. To give a brief overview of our strategy, we initially relied on a linear glycosylation approach for the synthesis of chitobiosyl azide 9 featuring parallel steps for the monomeric donor $(\mathbf{4 b}-\mathbf{7 b})$ and acceptor (4a-7a) building blocks. Since the azide moieties of the acceptor building blocks provide excellent protection of the reducing end and modular approaches gave inferior yields, we chose azide protection at the very beginning. The $\beta$-mannoinversion of $\beta$-gluco-trisaccharide $\mathbf{1 4}$ to compound $\mathbf{1 5}$ on the way to the trimeric core structure represented one of the major synthetic challenges, which was overcome by inversion via a $\mathrm{S}_{\mathrm{N}} 2-$ substitution of the triflate moiety of compound $\mathbf{1 4}$. 


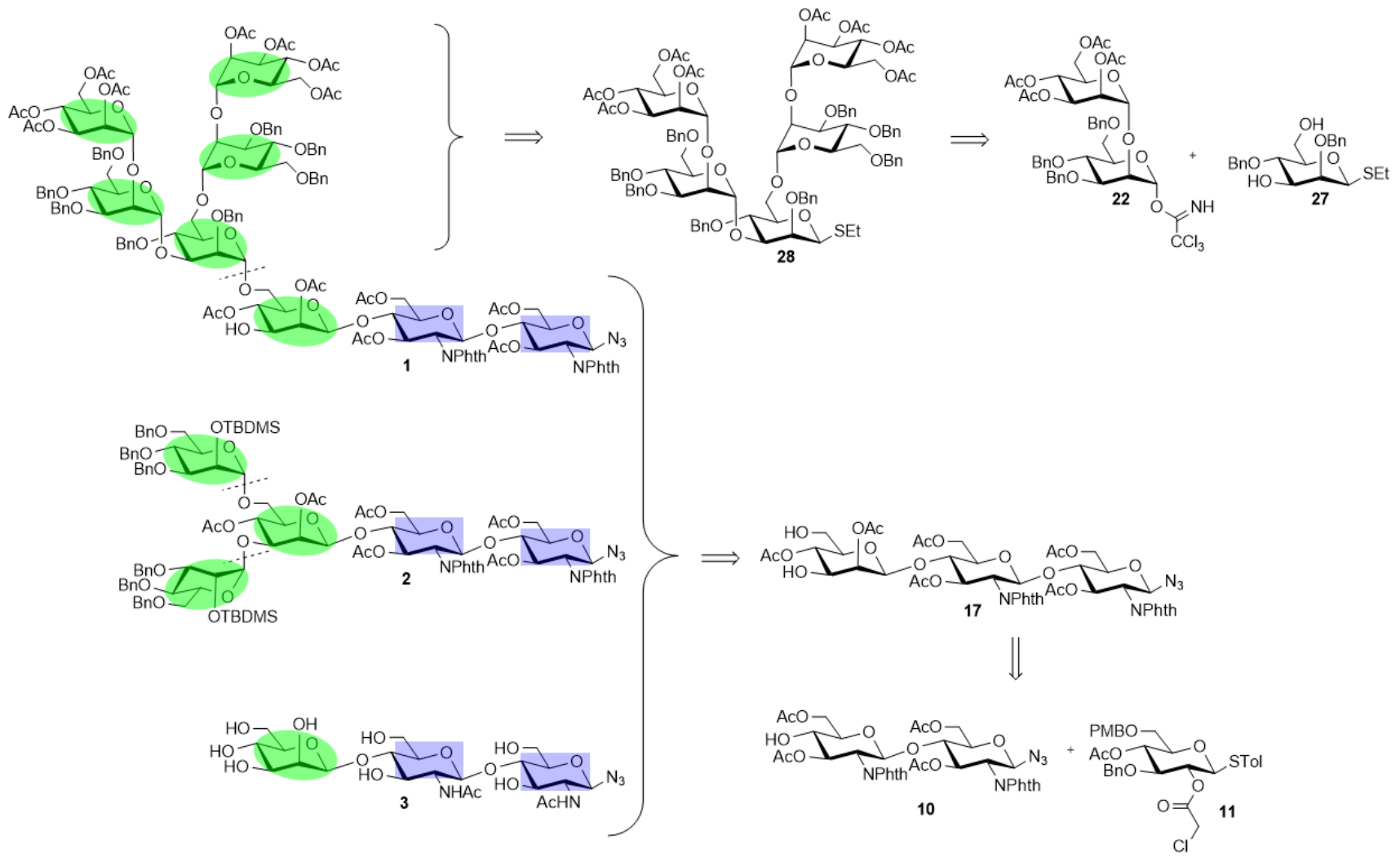

Figure 2. Retrosynthetic approach for azido-glycans 1, 2, and 3: Man 6 (GlcNPhth) ${ }_{2} \mathrm{~N}_{3}$ (1) was obtained by convergent block glycosylation of key acceptor 17 and pentamannoside donor 28; pentasaccharide structure $\mathrm{Man}_{3}(\mathrm{GlcNPhth})_{2} \mathrm{~N}_{3}(\mathbf{2})$ was obtained by tandem glycosylation of key acceptor $\mathbf{1 7}$ and an arbitrary mannose based donor; the native trimeric key structure Man(GlcNPhth) ${ }_{2} \mathrm{~N}_{3}(\mathbf{2})$ was achieved by glycosylation of chitobiosyl azide $\mathbf{1 0}$ and thio-tolyl donor $\mathbf{1 1}$ followed by subsequent deprotection steps.

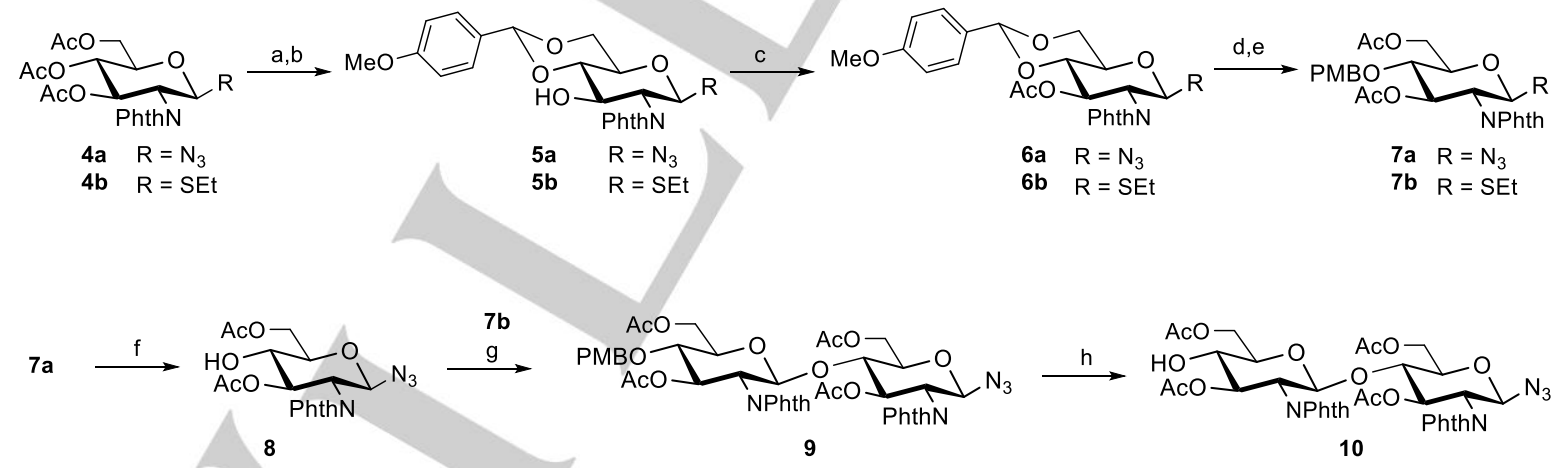

Scheme 1. Synthesis of chitobiosyl azide 10; a) $\mathrm{NaOMe}, \mathrm{MeOH}, \mathrm{rt}, 30 \mathrm{~min}\left(\mathrm{R}=\mathrm{SEt}, \mathrm{N}_{3}\right.$, quant.); b) p-methoxybenzaldehyde dimethyl acetal, $p$-TsOH, MeCN, rt, $\left.4 \mathrm{~h},\left(\mathrm{R}=\mathrm{SEt}, 84 \% ; \mathrm{R}=\mathrm{N}_{3}, 72 \%\right) ; \mathrm{c}\right) \mathrm{Ac} 2 \mathrm{O}$, Pyridine, rt, $\left.\left.16 \mathrm{~h},\left(\mathrm{R}=\mathrm{SEt}, 97 \% ; \mathrm{R}=\mathrm{N}_{3}, 92 \%\right) ; \mathrm{d}\right) \mathrm{BH}_{3} \cdot \mathrm{THF}, \mathrm{TMSOTf}, 0{ }^{\circ} \mathrm{C}, 1.5 \mathrm{~h},(\mathrm{R}=\mathrm{SEt}, 69 \% ; \mathrm{R}=\mathrm{N}, \mathrm{N}, 85 \%) ; \mathrm{e}\right)$ $\mathrm{Ac}_{2} \mathrm{O}$, pyridine, rt, $16 \mathrm{~h}$, (R = SEt, 99\%; $\left.\mathrm{R}=\mathrm{N}_{3}, 92 \%\right)$; f) DDQ, $\mathrm{CH}_{2} \mathrm{Cl}_{2} / \mathrm{H}_{2} \mathrm{O}$, rt, $\left.\left.4 \mathrm{~h}, 79 \% ; \mathrm{g}\right) \mathrm{NIS}, \mathrm{AgOTf} \mathrm{CH}_{2} \mathrm{Cl}_{2}, 30{ }^{\circ} \mathrm{C}, 2.5 \mathrm{~h} ; \mathrm{h}\right) \mathrm{DDQ}, \mathrm{CH}_{2} \mathrm{Cl}_{2} / \mathrm{H}_{2} \mathrm{O}, \mathrm{rt}, 4 \mathrm{~h}, 86 \%(2$ steps).

The key acceptor compound $\mathbf{1 7}$ was obtained after deprotection steps proceeding from $\mathbf{1 5}$. Further, the pentamannoside 28 was obtained by glycosylation of the trichloroacetimidate (TCA) disaccharide donor $\mathbf{2 2}$ and 3,6-diol acceptor $\mathbf{2 7}$ in a good yield. For the synthesis of the conserved pentasaccharide core structure 2, we performed a tandem glycosylation of key structure $\mathbf{1 7}$ as an acceptor and 29 as donor as shown in Scheme 6 . The protected octameric glycan 1 was obtained by the assembly of branched pentamannose antenna 28 and trisaccharide azide 17 by block glycosylation. Global deprotection 
of key structure $\mathbf{1 7}$ yielded the native trisaccharide $\mathbf{3}$, which was successfully clicked to the $F_{a b}$ fragment of Herceptin ${ }^{121 \rightarrow B C N}$ via SPAAC ligation, leading to previously published 3-BCN-Her. ${ }^{[20]}$

\section{Synthesis of chitobiosyl azide (GIcNAc) ${ }_{2} \mathrm{~N}_{3}$ (10)}

As outlined in Scheme 1, starting from monosaccharide precursors $\mathbf{4 a}$ and $\mathbf{4 b}$, which were accessible in a five-step sequence commencing from glucosamine hydrochloride on multi gram scale (see supplementary data), the synthesis of chitobiosyl azide 9 was performed in a modular way. ${ }^{[21]}$ Early introduction of the azido moiety at the reducing end for precursor $4 a$ turned out to be advantageous for chemical stability against later glycosylation steps. Likewise, implementation of the thioethyl moiety for monomer $\mathbf{4} \mathbf{b}$ as a prevalent donor for specific activation with $\mathrm{N}$-iodosuccinimide (NIS) proved to be suitable for the following protecting and deprotecting steps. ${ }^{[22]}$ Deacetylation under basic conditions was followed by acid-catalyzed 4,6- $p$ methoxybenzylidene-acetal protection to form 4,6-di-Obenzylidene acetals $\mathbf{5 b}$ and $\mathbf{5 a}$. The remaining $2-\mathrm{OH}$ group of compounds $\mathbf{5 b}$ and $\mathbf{5 a}$ underwent esterification by treatment with acetic anhydride in pyridine, delivering acetylated monomers $6 \mathbf{b}$ and $\mathbf{6 a} .^{[21]}$ The fully protected compounds $\mathbf{6} \mathbf{b}$ and $\mathbf{6 a}$ were then regioselectively deprotected at the 4-position by reductive ring opening in the presence of $\mathrm{BH}_{3}$. THF complex and trimethylsilyl triflate, then acetylated at the 6-position to give access to $\mathbf{7 b}$ and 7a. The configuration of $\mathbf{7 b}$ was confirmed by X-ray crystallography (see CCDC). Afterwards, para-methoxy benzyl (PMB) deprotection of $7 a$ resulted in the monomeric C-3 acceptor $\mathbf{8}$. The desired azide-bearing acceptor $\mathbf{8}$ and thioglycosilated donor $\mathbf{7 b}$ were prepared in excellent overall yields of $24 \%$ over eleven steps and $33 \%$ over ten steps, respectively. Subsequent glycosylation of donor $\mathbf{7 b}$ and acceptor $\mathbf{8}$ yielded the chitobiosyl azide 9. ${ }^{[23]}$ Finally, repeating PMB deprotection of compound 9 furnished chitobiosyl azide 10, which served as an acceptor for glycosylation with $\beta$-thio-tolyl donor $\mathbf{1 1}$. This highly reproducible two step protocol opened access to disaccharide acceptor $\mathbf{1 0}$ on a multigram scale with a yield of $86 \%$ over two steps.

\section{Synthesis of the core trimer: $\mathrm{N}$-glycan $\operatorname{Man}_{3}(\mathrm{GICNAC})_{2} \mathrm{~N}_{3}(17)$}

The following glycosylation reaction for $\beta$-gluco trisaccharide 12c was explored using the three prepared $\beta$-thio-tolyl donors 11a-c (see Table 1). For activation of the thioglycosides two different promoter systems were tested. On the one hand the NIS/AgOTfsystem and on the other the DMDS/ $/ \mathrm{Tf}_{2} \mathrm{O}$-system was attempted. ${ }^{[24]}$ As shown in Table 1, the $\mathrm{DMDS} / \mathrm{Tf}_{2} \mathrm{O}$ activation method was found to be superior for acetal protected donors 11a and $\mathbf{1 1 b}$, but still providing low yields of $16 \%$ and $31 \%$, respectively. Fortunately, utilizing thio-tolyl donor $11 \mathrm{c}$ by activation with NIS/AgOTf promoter system at $-40{ }^{\circ} \mathrm{C}$, proved to be the most efficient method and gave a satisfying yield of $50 \%$. Next, one of the major synthetic challenges was the $\beta$-mannoinversion of $\beta$-gluco-trisaccharide $\mathbf{1 4}$ described in Scheme 2 (b-d). Mild hydrolysis of the mono-chloroacetic group of trisaccharide 12c using thiourea unblocked the C-2 position. Introducing a trifluoromethylsulfonyloxy group (triflate) at the C-2 position of compound 13 by treatment with $\mathrm{Tf}_{2} \mathrm{O}$ in pyridine/dichloromethane at $-15^{\circ} \mathrm{C}$ led to compound 14 , on which inversion from the gluco- to manno-form was carried out: The triflate group of trimeric building block 14 was displaced by an acetyl group at C-2 position to obtain the $\beta$-manno-trimer 15 , presented in Scheme 2. ${ }^{[25]}$

Reaction conditions regarding the $\mathrm{S}_{\mathrm{N}} 2$-inversion protocol to obtain the $\beta$-manno-configuration of core trisaccharide 15 at the $\mathrm{C}-2$ position were optimized. Using 18-crown-6 and CsOAc as a base in DMF at $60^{\circ} \mathrm{C}$, a yield of $70 \%$ of trimeric structure 13 could be achieved and full inversion was gained; no other isomer was detected. The $\beta$-manno configuration of compound 13 was confirmed by NMR-experiments, measuring characteristic ${ }^{1} J_{\mathrm{CH}}$ coupling constant of $157.5 \mathrm{~Hz}$ for the C-2 inverted position. ${ }^{[26]}$

To achieve the 3,6-diol acceptor 17 , which was needed for later azido- $\mathrm{N}$-glycan synthesis towards octameric and pentameric key structures (1 and 2), first, the p-methoxy benzyl (PMB) moiety at C-6 position of trimer 15 was cleaved oxidatively with DDQ in a mixture of water and dichloromethane. Subsequently, oxidative debenzylation of $\mathrm{C}-3$ position of compound $\mathbf{1 6}$ was performed by using $\mathrm{NaBrO}_{3}$ and $\mathrm{Na}_{2} \mathrm{~S}_{2} \mathrm{O}_{4}$ in a biphasic system of water and ethyl acetate at room temperature, resulting in 3,6-diol acceptor 15. ${ }^{[27]}$

Table 1. Exploration of the glycosylation reaction to trisaccharide compounds with chitobiosyl acceptor 10. Three different thio-tolyl donors 11a-c were examined; promotor systems and temperature were varied to obtain compounds $12 \mathrm{a}-\mathrm{c}$ at different yields. The NIS/AgOTf promoter system in combination with compound 11c proved to be the most efficient and additionally simplified the protecting group strategy for the following steps.

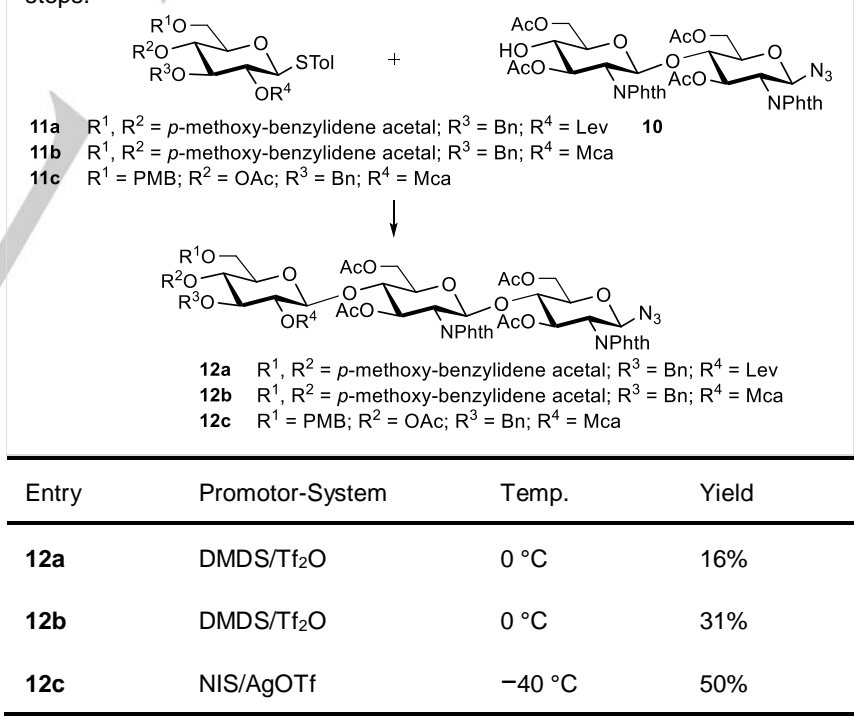

Synthesis of an $\mathrm{N}$-glycan arm: dimannoside-donor $\mathrm{Man}_{2} \mathrm{SEt}$ (22)

We proceeded with the sequence of dimannoside-donor 22 (Scheme 3), which was needed as a precursor building block for branched pentamannoside antenna 28 (Scheme 5). Thus, the monomeric thioethyl donor 18 and 2-OH acceptor 19 were synthesized by standard protection and deprotection procedures, described in detail in the supplementary data. ${ }^{[22,28]}$ Afterwards, the disaccharide building block $\mathbf{2 0}$ was obtained via glycosylation 
with the compounds 18 and 19 with NIS/TMSOTf as a promotor system at $-40^{\circ} \mathrm{C}$ (Scheme 3 ). Since strongly electronwithdrawing groups like the 2,3,4,6-tetra-O-acetyl groups of mannoside 16 are expected to disfavour oxacarbenium ion formation, glycosylation occurs by $\mathrm{S}_{\mathrm{N}} 2$-like displacement of the $\beta$-anomeric sulfonium ion, leading to $\alpha$-glycosidic linkage, as observed for compound 20.[29] Afterwards, the tert-butyl dimethylsilyl (TBS) group at the anomeric position the dimannoside $\mathbf{2 0}$ was removed in the presence of tetrabutylammonium fluoride (TBAF) yielding $62 \%$ of the disaccharide 21. ${ }^{[28 c, 29 b]}$ Subsequent conversion using trichloroacetonitril and 1,8-diazabicycloundec-7-ene (DBU) provided the Schmidt donor, trichloroacetimidate compound $\mathbf{2 2}$, with a yield of $72 \%$ (Scheme 3$).{ }^{[28 e]}$

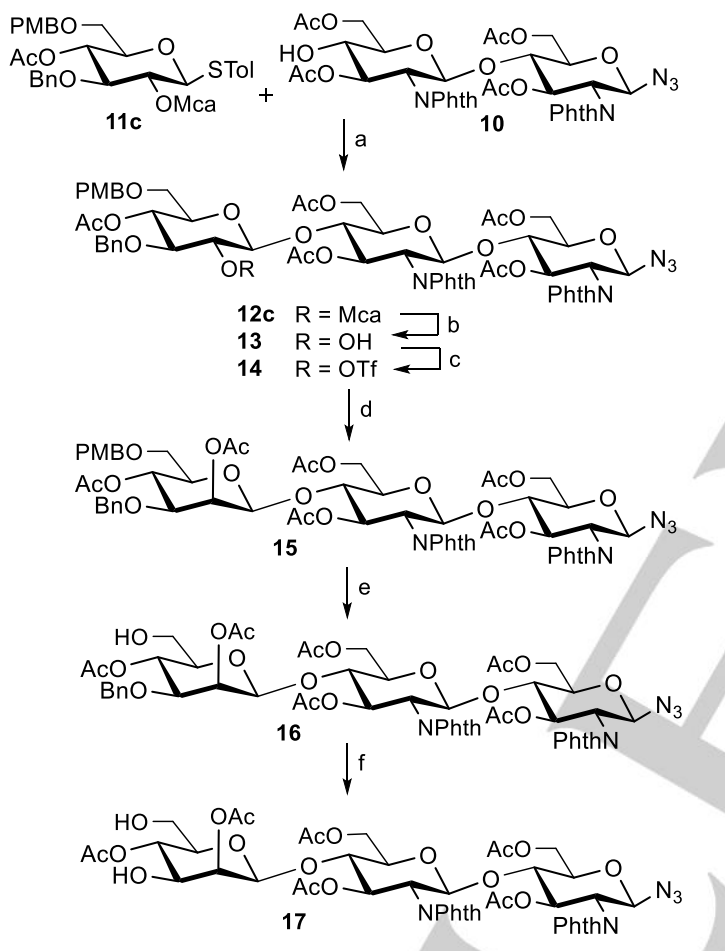

Scheme 2: Synthesis of trimeric key structure 17; a) NIS, $\mathrm{AgOTf}, \mathrm{CH}_{2} \mathrm{Cl}_{2}$, $-40{ }^{\circ} \mathrm{C}, 2 \mathrm{~h}, 50 \%$; b) thiourea, $\mathrm{NaHCO}_{3}, \mathrm{EtOH}$, reflux, $6 \mathrm{~h}, 99 \%$; c) $\mathrm{Tf}_{2} \mathrm{O}$, pyridine, $\mathrm{CH}_{2} \mathrm{Cl}_{2},-15^{\circ} \mathrm{C}$ to rt, $2.5 \mathrm{~h}$, quant.; d) $\mathrm{CsOAc}$, 18-crown-6, DMF, $60{ }^{\circ} \mathrm{C}$, $16 \mathrm{~h} ; 70 \%$; e) DDQ, $\mathrm{CH}_{2} \mathrm{Cl}_{2} / \mathrm{H}_{2} \mathrm{O}$, rt, 2.5 h, 93\%; f) $\mathrm{NaBrO}_{3}, \mathrm{Na}_{2} \mathrm{~S}_{2} \mathrm{O}_{4}, \mathrm{EtOAc} / \mathrm{H}_{2} \mathrm{O}$, rt, 9 h, $58 \%$.

\section{Synthesis of the branching point: 3,6-diol acceptor (27)}

In Scheme 4 we present a brief reaction sequence for 3,6-diolfunctionalized acceptor $\mathbf{2 7}$, which at the same time serves as a donor for further glycosylation purposes due to its thioethyl moiety. The trifunctional donor/acceptor monomer 27 was obtained starting from commercially available D-mannose 23. After peracetylation, mannoside $\mathbf{2 4}$ was coupled with ethanthiol in the presence of $\mathrm{BF}_{3} \cdot \mathrm{OEt}_{2}$ to obtain thioethyl compound 18, whose structure could be confirmed by X-ray cristallography. ${ }^{[28 a]}$ After deprotection of the acylester, the 2,3:4,6-di-O-benzylidene protection of compound $\mathbf{2 6}$ was achieved by using benzaldehyde dimethyl acetal and camphor-10-sulfonic acid. ${ }^{[30]}$ Subsequent $\mathrm{Cu}(\mathrm{OTf})_{2}$-catalyzed regioselective reductive 0 -3,6-ring opening as a late-stage introduction of the acceptor's 1,3- and 1,6-arms was conducted by adding boron hydride complex $\mathrm{BH}_{3} \cdot \mathrm{THF}$ at $0{ }^{\circ} \mathrm{C}$ to the reaction mixture. ${ }^{[31]}$ The regioselective 3,6-diol formation to compound $\mathbf{2 7}$ was verified by the HMBC NMR experiment.

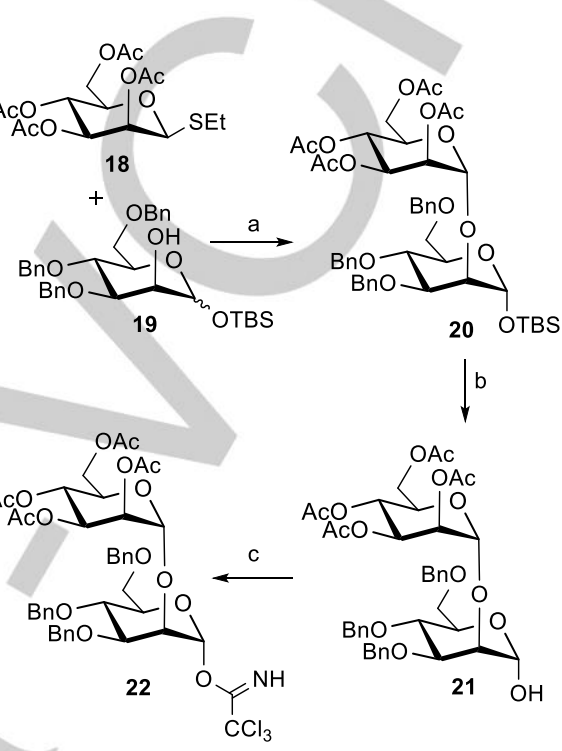

Scheme 3: Synthesis of disaccharide trichloroacetimidate donor 22; a) NIS, TMSOTf, $\mathrm{CH}_{2} \mathrm{Cl}_{2}$, MS $4 \AA$, $-40{ }^{\circ} \mathrm{C}, 2 \mathrm{~h}, 40 \%$; b) TBAF, THF, $0{ }^{\circ} \mathrm{C}, 1 \mathrm{~h}, 62 \%$; c) $\mathrm{CCl}_{3} \mathrm{CN}, \mathrm{DBU}, \mathrm{CH}_{2} \mathrm{Cl}_{2}, 0^{\circ} \mathrm{C}, 1 \mathrm{~h}, 72 \%$.

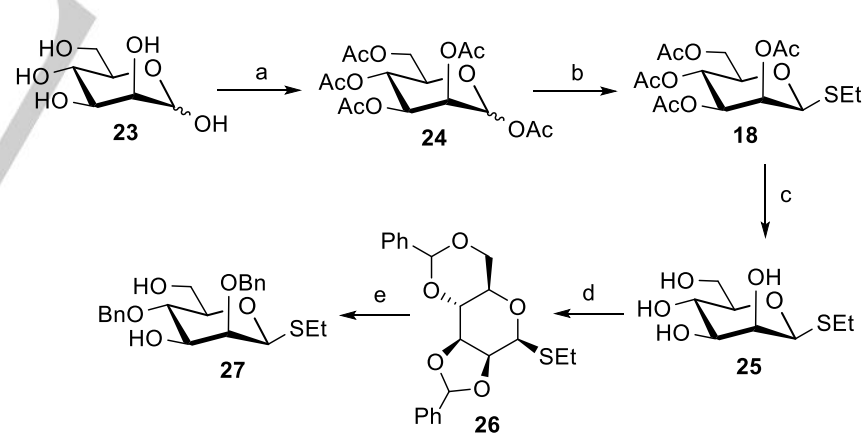

Scheme 4: Synthesis 3,6-diol acceptor 27; a) $\mathrm{Ac}_{2} \mathrm{O}, \mathrm{l}_{2}, \mathrm{rt}, 2 \mathrm{~h}, 91 \%$; b) $\mathrm{EtSH}$, $\mathrm{BF}_{3} \cdot \mathrm{OEt}_{2}, \mathrm{CH}_{2} \mathrm{Cl}_{2}, 0^{\circ} \mathrm{C}$ to rt, $16 \mathrm{~h}$; c) NaOMe, MeOH, rt, $6 \mathrm{~h}, 64 \%$ (2 steps); d) benzaldehyde dimethyl acetal, CSA, DMF, rt, 16 h, 84\%; e) $\mathrm{BH}_{3} \cdot \mathrm{THF}, \mathrm{Cu}(\mathrm{OTf})_{2}$, $\mathrm{CH}_{2} \mathrm{Cl}_{2}, 0^{\circ} \mathrm{C}$ to rt, $2 \mathrm{~h}, 31 \%$.

\section{Synthesis of branched core pentamannoside $\operatorname{Man}_{5} \mathrm{SEt}(28)$}

As shown in Scheme 5, Schmidt tandem glycosylation was carried out with trichloroacetimidate donor 22 and 3,6-diolfunctionalized acceptor $\mathbf{2 7}$ under TMSOTf activation conditions at $-20^{\circ} \mathrm{C}$, leading to branched pentamannoside 28 with a yield of $50 \%{ }^{[32]}$ The thioethyl moiety of compound 27 remains unaffected under the reaction conditions, leaving $\mathbf{2 8}$ as a donor for the following reactions. 
To confirm the structure of pentamer 28, full NMR assignment was desired. The high grade of signal overlap especially in the ${ }^{1} \mathrm{H}$ frequency necessitated acquiring spectra beyond the common set of ${ }^{1} \mathrm{H}-{ }^{1} \mathrm{H}$ and ${ }^{1} \mathrm{H}-{ }^{13} \mathrm{C} \quad 2 \mathrm{D}$ experiments. Therefore, a $1,1-$ ADEQUATE experiment was recorded, providing highly resolved information on ${ }^{13} \mathrm{C}-{ }^{13} \mathrm{C}$ pairs at the price of long measurement duration. ${ }^{[33]}$ Full assignment of all signals as shown in Figure 3 could be achieved, and subsequently inter-ring linkage and the position of protection groups could be confirmed. Unfortunately, for the larger compounds, the amount of sample was too low for similar NMR analysis.

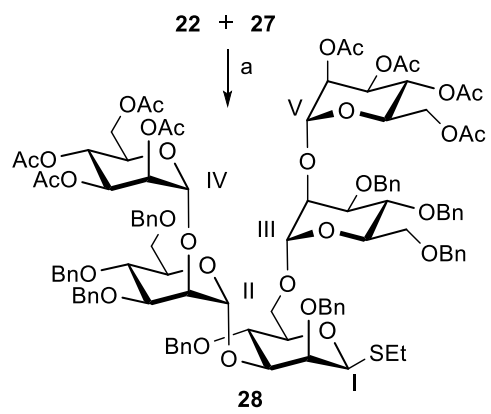

Scheme 5: Synthesis of branched pentamannose antenna 28; a) TMSOTf, $\mathrm{CH}_{2} \mathrm{Cl}_{2}, \mathrm{MS} 4 \AA$, $-20^{\circ} \mathrm{C}$ to $0^{\circ} \mathrm{C}, 50 \%$.

\section{Synthesis of Azido-N-glycan $\operatorname{Man}_{3}(\mathrm{GlcNAC})_{2} \mathrm{~N}_{3}(2)$}

The simple mannose-based donor 29 was obtained in eight steps from commercially available D-mannose (see supporting information) and used in tandem glycosylation with trimeric 3,6acceptor 17 in the presence of NIS/AgOTf at $-40^{\circ} \mathrm{C}$ to yield the pentameric glycan $\mathrm{Man}_{3} \mathrm{Glc}(\mathrm{GlcNAc})_{2} 2$ (Scheme 6). ${ }^{[24 a, 34]}$ The doubly-glycosylated product could be isolated in a satisfying yield of $38 \%$. Only minor quantities of singly-glycosylated side product were isolated alongside. The glycopattern of pentamer $\mathbf{2}$ is of interest as it represents the common pentasaccharide core structure of naturally occuring $\mathrm{N}$-glycans.

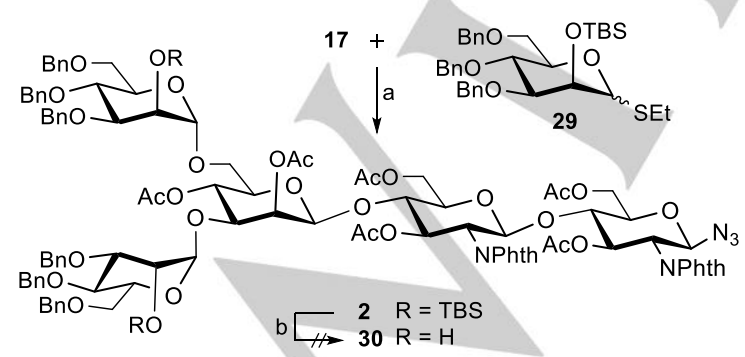

Scheme 6: Synthesis of key pentasaccharide $\mathrm{Man}_{3} \mathrm{NAc}_{2} 2$; a) NIS, AgOTf, $\mathrm{CH}_{2} \mathrm{Cl}_{2}, \mathrm{MS} 4 \AA,-40^{\circ} \mathrm{C}, 2 \mathrm{~h}, 38 \%$; b) TBAF, THF, $0{ }^{\circ} \mathrm{C}$ to rt.

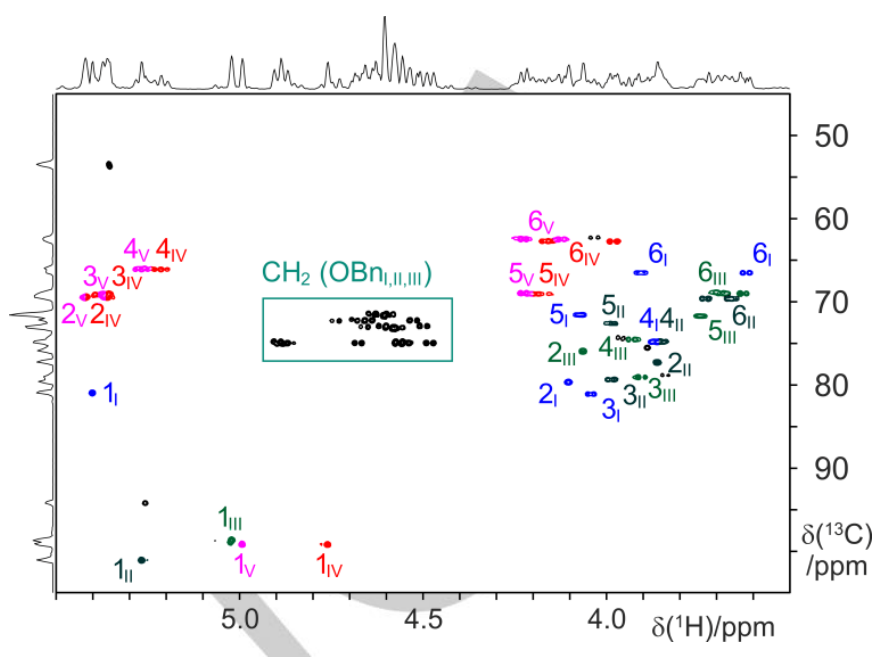

Figure 3. ${ }^{1} \mathrm{H}-{ }^{13} \mathrm{C}$ HSQC spectrum (heteronuclear 2D NMR) of pentameric structure 28 in $\mathrm{CD}_{2} \mathrm{Cl}_{2}$ - The ring $\mathrm{CH}$-group region is shown with the full assignment of the ring $\mathrm{CH}$-groups achieved by evaluating 1,1-ADEQUATE, HSQC, HMBC, and homonuclear spectra (data not shown).

\section{Synthesis of Azido-N-glycan $\operatorname{Man}_{6}$ (GlcNPhth) ${ }_{2} \mathrm{~N}_{3}$ (1)}

As the assembly of pentamer 2 proved to be successful, we proceeded with the convergent block glycosylation of core trisaccharide $\mathbf{1 6}$ and an excess amount of branched pentamannose antenna 28 via activation with NIS/TMSOTf at $-40{ }^{\circ} \mathrm{C}$ (Scheme 7). Surprisingly, just one of the acceptor positions formed a glycosidic bond, resulting in azido-glycan $\mathbf{1}$, confirmed with MALDI-TOF experiments (see supplementary data). As the C-6-position is known to be more reactive than the C-3 position we assume structure 1 as shown in Scheme 7 was obtained. After subsequent deprotection of the remaining acetylgroups under Zemplén conditions with $\mathrm{NaOMe}$ in methanol, however, only fragments of the product could be detected my mass spectrometry and the deprotection of the azido-glycan could not be verified.

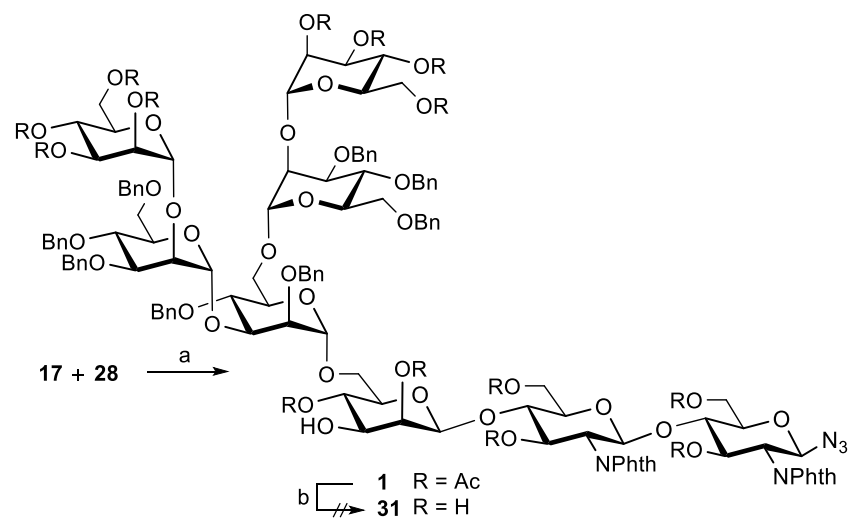

Scheme 7: Assembly of building blocks 17 and 28 to octameric azido-glycan Man(GlcNPhth) ${ }_{2} \mathrm{~N}_{3} 1$; a) NIS, TMSOTf, $\mathrm{CH}_{2} \mathrm{Cl}_{2}, \mathrm{MS} 4 \AA$, $-45^{\circ} \mathrm{C}, 2.5 \mathrm{~h}, 70 \%$; b) $\mathrm{NaOMe}, \mathrm{MeOH}, \mathrm{rt}, 4 \mathrm{~h}$. 


\section{Global deprotection of Azido-N-glycan Man(GIcNAc) ${ }_{2} \mathrm{~N}_{3}$ (3)}

In Scheme 8 the global deprotection of trimeric structure $\mathbf{1 6}$ to provide native $\mathrm{ManNAc}_{2} 3$ is shown. Removal of phthalimide moieties and saponification of acetyl esters were carried out simultaneously with an excess of ethylenediamine in $n$-butanol at $90{ }^{\circ} \mathrm{C}^{[27]}$ Afterwards, the crude product bearing free amine positions underwent direct $\mathrm{N}$-acetylation in a mixture of methanol and water in the presence of $\mathrm{Ac}_{2} \mathrm{O}$ to obtain the native trisaccharide ManGlcNAc ${ }_{2}$ 3. $^{[27]}$ Due to many unidentified byproducts, two consecutive rounds of purification via HPLC were necessary to isolate the pure core trisaccharide 3 in $55 \%$ yield over the two steps.

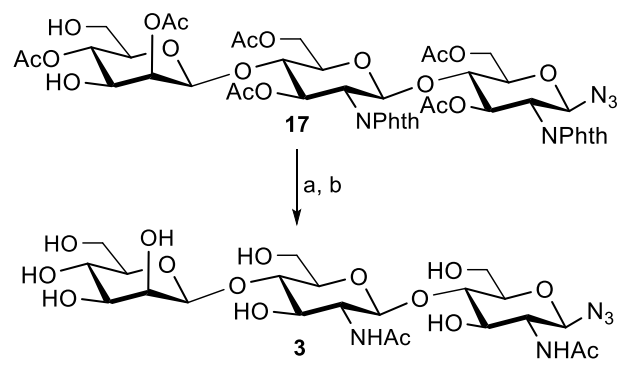

Scheme 8: Deprotection strategies of compound 17 to obtain native trisaccharide 3; a) Ethylenediamine, 1-Butanol, $90^{\circ} \mathrm{C}, 16 \mathrm{~h}$; b) $\mathrm{Ac}{ }_{2} \mathrm{O} / \mathrm{MeOH} / \mathrm{H}_{2} \mathrm{O}$ (1:10:1.5), rt, 16 h, $55 \%$.

The general applicability of azido-glycans for chemical glycomodification of proteins via SPAAC was already demonstrated by Koehler et al. using native azido-trisaccharide 3 . In Scheme 9, the corresponding SPAAC of the azido-glycan and the $F_{a b}$ fragment of Herceptin $\left(\operatorname{Her}^{121 \rightarrow B C N}\right)$ containing the cyclooctyne nAA endo-bicyclo[6.1.0]non-4-yne-lysin (BCN), is shown. ${ }^{[20]}$

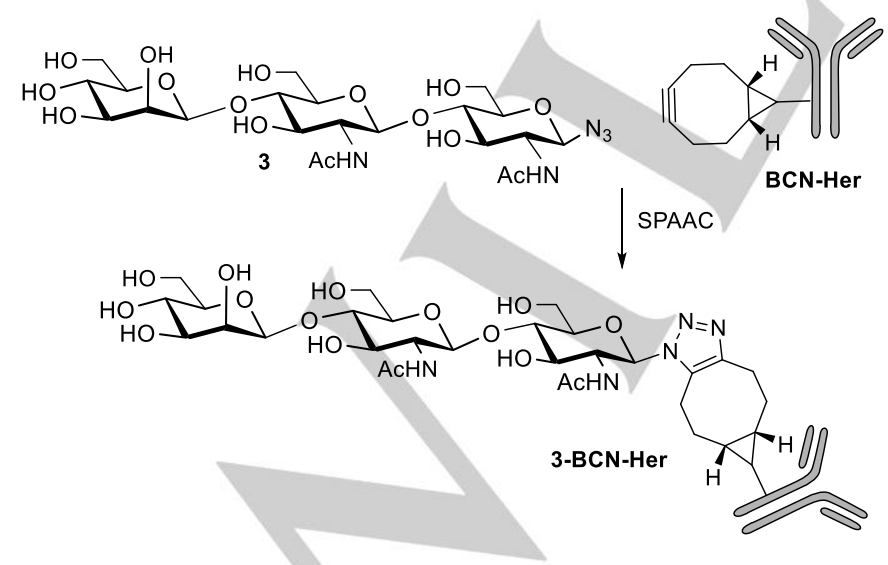

Scheme 9: Chemical ligation via SPAAC of native azido- $N$-glycan 3 and recombinantly modified $\mathrm{F}_{\mathrm{ab}}$ fragment of Herceptin $\mathbf{B C N}-\mathrm{Her}\left(\mathrm{Her}^{121 \rightarrow B C N}\right.$ ) to create neo-glycoprotein 3-BCN-Her.

\section{Conclusions}

We demonstrated a facile large scale chemical synthesis of the azide-functionalized $\mathrm{N}$-glycans $\mathbf{1}, \mathbf{2}$, and $\mathbf{3}$ via several strategies mentioned above. The key step for the common precursor structure was the assembly of the $\beta$-mannosidic linkage via inversion of a $\beta$-glucoside trisaccharide. From this precursor, an octameric glycan was created via block glycosylation and a deprotected core trisaccharide was successfully conjugated to the $F_{a b}$-fragment of a recombinantly modified human antibody containing a nAA to modify its glycostructure.

We will go on to attach different antenna to create a small library of glycans for biological evaluation and production of single glycoforms of proteins of therapeutical interest. As the carbohydrate motif has a significant effect on several properties of glycoproteins such as stability, function and immunogenicity, glycosylation needs to be considered but also provides new possibilities for pharmaceutical development.

\section{Experimental Section}

General information: Unless otherwise indicated, utilized solvents and chemicals were purchased from commercial suppliers (ABCR, ACROS, Alfa Aesar, Carl Roth; Fluka, Fisher SCIENTIFIC, MERCK, Sigma ALdRICH, VWR) and starting materials were used without further purification. Analytical thin-layer chromatography (TLC) was performed on silica gel 60 $\mathrm{F}_{254}$ precoated aluminium plates from MERCK with a layer thickness of $0.25 \mathrm{~mm}$ and with detection by UV $(\lambda=254 \mathrm{~nm}, 365 \mathrm{~nm})$. SEEBACHreagent $(2.5 \%$ phosphomolybdic acid, $1.0 \%$ cerium-(IV) sulfate tetrahydrate, $6.0 \%$ concentrated sulfuric acid, $90.5 \%$ destilled water) as dipping solution with subsequent heating by warm airflow. Purification was performed with preparative chromatography using normal-phase silica gel (Silica gel 60, 0.040-0.063 mm, from MERCK).

NMR samples were prepared as solutions and measured at room temperature. Spectra were recorded on a BRUKER $300 \mathrm{MHz}$ AVANCE spectrometer with room temperature Dual ${ }^{13} \mathrm{C} /{ }^{1} \mathrm{H}$ probe head $\left({ }^{1} \mathrm{H}-\mathrm{NMR}\right.$ spectra: $300 \mathrm{MHz},{ }^{13} \mathrm{C}-\mathrm{NMR}$ spectra: $63 \mathrm{MHz}$ ), a BRUKER $400 \mathrm{MHz}$ AVANCE spectrometer with room temperature BBI probe head ( ${ }^{1} \mathrm{H}-\mathrm{NMR}$ spectra: $400 \mathrm{MHz},{ }^{13} \mathrm{C}$-NMR spectra: $100 \mathrm{MHz}$ ), a BRUKER $500 \mathrm{MHz}$ AVANCE III HD spectrometer with cryogenically cooled BBO probe head ( ${ }^{1} \mathrm{H}-\mathrm{NMR}$ spectra: $500 \mathrm{MHz},{ }^{13} \mathrm{C}$-NMR spectra: $125 \mathrm{MHz}$ ), and a BRUKER $600 \mathrm{MHz}$ AVANCE III spectrometer with cryogenically cooled TCI probe head $\left({ }^{1} \mathrm{H}\right.$-NMR spectra: $600 \mathrm{MHz},{ }^{13} \mathrm{C}-\mathrm{NMR}$ spectra: $\left.150 \mathrm{MHz}\right)$. For ${ }^{1} \mathrm{H}-1 \mathrm{D}$ spectra, 65536 points were acquired in $5.3 \mathrm{~s}$ acquisition time with 16 scans, for ${ }^{13} \mathrm{C}-1 \mathrm{D}, 65536$ points were acquired in $0.9 \mathrm{~s}$ acquisition time with 128 scans. Chemical shifts $(\delta)$ are expressed in parts per million (ppm) and referenced to the deuterated solvents, either chloroform $\left({ }^{1} \mathrm{H}: \delta=7.26 \mathrm{ppm}\right.$; $\left.{ }^{13} \mathrm{C}: \delta=77.16 \mathrm{ppm}\right)$, methanol $\left({ }^{1} \mathrm{H}: \delta=2.50 \mathrm{ppm} ;{ }^{13} \mathrm{C}: \delta=49.00 \mathrm{ppm}\right)$, DMSO $\left({ }^{1} \mathrm{H}: \delta=2.50 \mathrm{ppm} ;{ }^{13} \mathrm{C}: \delta=39.43 \mathrm{ppm}\right)$ or dichloromethane $\left({ }^{1} \mathrm{H}: \delta\right.$ $\left.=5.32 \mathrm{ppm} ;{ }^{13} \mathrm{C}: \delta=53.5 \mathrm{ppm}\right)$ as internal standards. Coupling constants $(\mathcal{J})$ are expressed in Hertz $(\mathrm{Hz})$ as absolute values. Splitting patterns are designated as s (singlet), d (doublet), t (triplet), q (quartet), quin (quintet), $\mathrm{m}$ (multiplet), dd (doublet of doublets). Further, diastereotopic methylene protons are marked as $H_{a}$ and $H_{b}$. When obtained from DEPT (distortionless enhancement by polarization transfer) experiments, the number of protons attached to the respective carbon signals is indicated as ' + ' for $\mathrm{CH}$ - and $\mathrm{CH}_{3}$ - groups and '-' for $\mathrm{CH}_{2}$-groups. For structural determination of proton and carbon ring positions the following $2 \mathrm{D}$ experiments were recorded: COSY (correlation spectroscopy), ${ }^{1} \mathrm{H}-{ }^{13} \mathrm{C}$ - 
HSQC (heteronuclear single quantum coherence), and HMBC (heteronuclear multiple bond correlation). The $\mathrm{HSQC}$ and ${ }^{1} \mathrm{H}^{13} \mathrm{C}-$ multiplicity-edited HSQC were recorded with $2048 \times 512$ points in 142 and $8.5 \mathrm{~ms}$ acquisition time, respectively. The coupling delay was matched to $145 \mathrm{~Hz}$. Two scans were added with an overall measurement time of 29 min. The HMBC was recorded with $8192 \times 512$ points in 570 and $8.5 \mathrm{~ms}$ acquisition time, respectively. The transfer delay was matched to $8 \mathrm{~Hz}$, a threefold lowpass filter was utilized to remove ${ }^{1} \mathrm{~J}_{\mathrm{CH}}$-correlations. Eight scans were added with an overall measurement time of $1 \mathrm{~h} 53 \mathrm{~min}$. For the pentameric structure 28, also an 1,1-ADEQUATE (adequate double quantum transfer experiment) was recorded on the $600 \mathrm{MHz}$ spectrometer using a sample of $10 \mathrm{mg}$ substance dissolved in dichloromethane- $d_{2}$. The 1,1-ADEQUATE was recorded with $4096 \times 1024$ points in 285 and $10.6 \mathrm{~ms}$ acquisition time, respectively. The heteronuclear coupling delay was matched to $145 \mathrm{~Hz}$, the homonuclear coupling delay was matched to $45 \mathrm{~Hz} ; 64$ scans were added with an overall measurement time of 28 hours.

ESI-MS (electrospray ionization mass spectrometry) and FAB-MS (fast atom bombardment mass spectrometry) measurements were performed by the use of an AGILENT TECHNOLOGIES 6230 TOF LC/MS and a FINNAGAN MAT 95 device. The molecule ion peak $[\mathrm{M}]^{+}$or the protonated $[\mathrm{M}+\mathrm{H}]^{+}$and deprotonated $[\mathrm{M}-\mathrm{H}]^{+},[\mathrm{M}+\mathrm{Na}]^{+}$or $[\mathrm{M}+\mathrm{K}]^{+}$form as well as characteristic fragments were indicated as the ratio of mass to charge with respect to their relative intensity to the base signal $(100 \%)$. High resolution mass was indicated by the calculated and measured value of the relating compound. MALDI-TOF (matrix assisted laser desorption/ionization-time of flight) mass spectra were recorded on an AB SCIEX 4800 Proteomics analyzer and a BRUKER Autoflex II Smartbeam device, using a nitrogen laser $(\lambda=$ $337 \mathrm{~nm}$ ) and software FlexControl version1.1 as well as XMASS-XTOF version 5.1.1. On a standard aluminum target plate (386 spots) from BRUKER CHCA and DHB (1:1) in $\mathrm{H}_{2} \mathrm{O}+0.1 \%$ THF/ACN $+0.1 \%$ THF $(1: 1)$ were utilized as matrix. Mass spectra were acquired in the reflector positive ion mode, default calibration.

IR (infrared spectroscopy) data were recorded on a BRUKER IFS 88. The measurements were performed either in between $\mathrm{KBr}$ plates or via ATR (attenuated total reflection) technique. The basis intensities were characterized in the following way: frequency of absorption $\left(\tilde{v}\right.$ in $\left.\mathrm{cm}^{-1}\right)$ and intensity of absorption as $\mathrm{s}=$ strong $(10-40 \%$ transmission), $\mathrm{m}=$ medium $(41-70 \%$ transmission), $\mathrm{w}=$ weak $(71-90 \%$ transmission) and $\mathrm{vw}=$ very weak (91-100\% transmission).

\section{O-(2,4-Di- $O$-acetyl-3-O-benzyl-6-O-p-methoxybenzyl- $\beta$-D-} mannopyranosyl)-(1 $\rightarrow 4)$-O-(3,6-di-O-acetyl-2-deoxy-2-phthalimido- $\beta$ D-glucopyranosyl)-(1 $\rightarrow 4)-3,6$-di- $O$-acetyl-2-deoxy-2-phthalimido- $\beta$-Dglucopyranosyl azide (15): To a solution of $14(280 \mathrm{mg}, 0.209 \mathrm{mmol}$, 1.00 eq.) in DMF (5.4 mL), dry CsOAc $(64.8 \mathrm{mg}, 0.230 \mathrm{mmol}, 1.10$ eq.) and 18-crown-6 $(64.8 \mathrm{mg}, 0.230 \mathrm{mmol}, 1.10 \mathrm{eq}$.) were added and stirred at $60^{\circ} \mathrm{C}$ overnight. The reaction mixture was diluted with dichloromethane, evaporated to dryness followed by column chromatographic purification using the eluent mixture ratio stated below to give compound 15 as a white solid (58\%).

$\boldsymbol{R}_{\mathbf{f}}=0.37$ (toluene/acetone $\left.=5: 1\right) .{ }^{1} \mathbf{H}-\mathbf{N M R}\left(500 \mathrm{MHz}, \mathrm{CDCl}_{3}\right): \delta=7.89$ $7.82\left(\mathrm{~m}, 4 \mathrm{H}, H_{\mathrm{Ar}}\right), 7.79-7.72\left(\mathrm{~m}, 4 \mathrm{H}, H_{\mathrm{Ar}}\right), 7.35-7.17\left(\mathrm{~m}, 7 \mathrm{H}, H_{\mathrm{Ar}}\right), 6.88$ $\left(\mathrm{d},{ }^{3} \mathrm{~J}=8.6 \mathrm{~Hz}, 2 \mathrm{H}, \mathrm{CH}_{\text {Arr }}\right), 5.76\left(\mathrm{dd},{ }^{3} \mathrm{~J}=10.2 \mathrm{~Hz},{ }^{3} \mathrm{~J}=9.0 \mathrm{~Hz}, 1 \mathrm{H}, 3-\mathrm{H}\right)$, $5.70\left(\mathrm{dd},{ }^{3} \mathrm{~J}=10.7 \mathrm{~Hz},{ }^{3} \mathrm{~J}=9.1 \mathrm{~Hz}, 1 \mathrm{H}, 3^{\prime}-\mathrm{H}\right), 5.57\left(\mathrm{~d},{ }^{3} \mathrm{~J}=9.4 \mathrm{~Hz}, 1 \mathrm{H}, 1-\right.$ H), $5.44\left(\mathrm{~d},{ }^{3} \mathrm{~J}=8.4 \mathrm{~Hz}, 1 \mathrm{H}, 1^{\prime}-\mathrm{H}\right), 5.48\left(\mathrm{~d},{ }^{3} \mathrm{~J}=2.8 \mathrm{~Hz}, 1 \mathrm{H}, 2^{\prime \prime}-\mathrm{H}\right), 5.05(\mathrm{t}$, $\left.{ }^{3} J=9.7 \mathrm{~Hz}, 1 \mathrm{H}, 4 "-H\right), 4.64\left(\mathrm{~d},{ }^{2} J=12.2 \mathrm{~Hz}, 1 \mathrm{H}, \mathrm{PhCH}_{\mathrm{a}} H_{b}\right), 4.44(\mathrm{~s}, 1 \mathrm{H}$, 1"-H), 4.42-4.33 (m, $5 \mathrm{H}, 6-\mathrm{H}_{b}, 6$ '- $\mathrm{H}_{b}, \mathrm{PhCH}_{a} \mathrm{H}_{\mathrm{b}}, \mathrm{MeOPhCH}_{2}$ ), 4.17 (dd, ${ }^{3} \mathrm{~J}$ $\left.=10.8 \mathrm{~Hz},{ }^{3} \mathrm{~J}=8.4 \mathrm{~Hz}, 1 \mathrm{H}, 2^{\prime}-\mathrm{H}\right), 4.27-4.23\left(\mathrm{~m}, 1 \mathrm{H}, 6^{\prime}-H_{\mathrm{a}}\right), 4.07\left(\mathrm{t},{ }^{3} \mathrm{~J}=\right.$ $9.9 \mathrm{~Hz}, 1 \mathrm{H}, 2-H), 3.96\left(\mathrm{t},{ }^{3} \mathrm{~J}=9.4 \mathrm{~Hz}, 1 \mathrm{H}, 4-H\right), 3.90\left(\mathrm{t},{ }^{3} J=9.5 \mathrm{~Hz}, 1 \mathrm{H}\right.$, 4'-H), $3.80\left(\mathrm{~s}, 3 \mathrm{H}, \mathrm{OCH}_{3}\right), 3.83-3.69\left(\mathrm{~m}, 3 \mathrm{H}, 5-H, 6-H_{a}, 5 '-H\right), 3.52-3.45$ (m, $\left.3 \mathrm{H}, 3 "-H, 6 "-H_{2}\right), 3.41-3.36(\mathrm{~m}, 1 \mathrm{H}, 5 "-H), 2.10$ (s, $3 \mathrm{H}, \mathrm{CH}_{3} \mathrm{CO}$ ), 2.09 (s, $3 \mathrm{H}, \mathrm{CH}_{3} \mathrm{CO}$ ), 1.95 (s, $\left.3 \mathrm{H}, \mathrm{CH}_{3} \mathrm{CO}\right), 1.90\left(\mathrm{~s}, 3 \mathrm{H}, \mathrm{CH}_{3} \mathrm{CO}\right), 1.88(\mathrm{~s}, 3 \mathrm{H}$, $\mathrm{CH}_{3} \mathrm{CO}$ ), 1.82 (s, $3 \mathrm{H}, \mathrm{CH}_{3} \mathrm{CO}$ ) ppm. $-{ }^{13} \mathrm{C}-\mathrm{NMR}\left(125 \mathrm{MHz}, \mathrm{CDCl}_{3}\right): \delta=$ $170.8\left(\mathrm{C}_{\mathrm{q}}, \mathrm{CO}\right), 170.7\left(\mathrm{C}_{\mathrm{q}}, \mathrm{CO}\right), 170.3\left(\mathrm{C}_{\mathrm{q}}, \mathrm{CO}\right), 170.2\left(\mathrm{C}_{\mathrm{q}}, \mathrm{CO}\right), 169.9\left(\mathrm{C}_{\mathrm{q}}\right.$, CO), $169.8\left(\mathrm{C}_{\mathrm{q}}, \mathrm{CO}\right), 168.0\left(\mathrm{C}_{\mathrm{q}}, \mathrm{CO}\right), 167.4\left(\mathrm{C}_{\mathrm{q}}, \mathrm{CO}\right), 159.4\left(\mathrm{C}_{\mathrm{q}}, \mathrm{C}_{\mathrm{Ar}}\right), 137.5$ $\left(\mathrm{C}_{\mathrm{q}}, \mathrm{C}_{\mathrm{Ar}}\right), 134.6\left(+, \mathrm{CH}_{\mathrm{Ar}}\right), 131.3\left(\mathrm{C}_{\mathrm{q}}, \mathrm{C}_{\mathrm{Ar}}\right), 129.8\left(\mathrm{C}_{\mathrm{q}}, \mathrm{C}_{\mathrm{Ar}}\right), 129.6\left(+, \mathrm{CH}_{\mathrm{Ar}}\right)$, $128.5\left(+, \mathrm{CH}_{\mathrm{Ar}}\right), 128.0\left(+, \mathrm{CH}_{\mathrm{Ar}}\right), 128.5\left(+, \mathrm{CH}_{\mathrm{Ar}}\right), 127.9\left(+, \mathrm{CH}_{\mathrm{Ar}}\right), 124.0(+$, $\left.\mathrm{CH}_{\mathrm{Ar}}\right), 113.9\left(+, \mathrm{CH}_{\mathrm{Ar}}\right), 98.0\left(+, C-1^{\prime \prime}\right), 97.6\left(+, C-1^{\prime}\right), 85.5(+, C-1), 76.5(+$, C-3"), $75.3(+, C-4), 74.1\left(+, C-5{ }^{\prime \prime}\right), 74.5(+, C-4$ ), $74.6(+, C-5), 73.3(-$, $\left.\mathrm{PhCH}_{2}\right), 72.8\left(+, \mathrm{C}^{\prime} 5^{\prime}\right), 71.0\left(-, \mathrm{PhCH}_{2}\right), 70.0\left(+, \mathrm{C}^{\prime} 3^{\prime}\right), 70.7(+, \mathrm{C}-3), 69.4$ $\left(-, C-6^{\prime \prime}\right), 68.3\left(+, C-4^{\prime \prime}\right), 67.1\left(+, C-2^{\prime \prime}\right), 62.4\left(-, C-6^{\prime}\right), 61.8(-, C-6), 55.0$ $\left(+, C-2^{\prime}\right), 55.4\left(+, \mathrm{OCH}_{3}\right), 54.6(+, C-2), 21.0\left(+, \mathrm{CH}_{3} \mathrm{CO}\right), 20.6(+, 2 \times$ $\left.\mathrm{CH}_{3} \mathrm{CO}\right), 20.8\left(+, \mathrm{CH}_{3} \mathrm{CO}\right), 20.9\left(+, \mathrm{CH}_{3} \mathrm{CO}\right)$ ppm. - IR (ATR): $\tilde{v}=2929$ $(\mathrm{vw}), 2117(\mathrm{vw}), 1777(\mathrm{vw}), 1741(\mathrm{w}), 1714(\mathrm{w}), 1612(\mathrm{vw}), 1513(\mathrm{vw}), 1467$ (vw), $1366(w), 1217(w), 1172(w), 1028(w), 972(w), 873(v w), 819(v w)$, $740(\mathrm{vw}), 720(\mathrm{w}), 643(\mathrm{vw}), 599(\mathrm{vw}), 566(\mathrm{vw}), 530(\mathrm{vw}), 477(\mathrm{vw}), 455$ $(\mathrm{vw}), 388(\mathrm{vw}) \mathrm{cm}^{-1}$. - MS (3-NBA, FAB): $\mathrm{m} / \mathrm{z}(\%): 1273(84)[\mathrm{M}+\mathrm{Na}]^{+}$, $1251(5)\left[\mathrm{M}+\mathrm{H}^{+}, 662(69), 647\right.$ (82), 365 (100).

$O$-(2,4-Di-O-acetyl-3-O-benzyl- $\beta$-D-mannopyranosyl)-(1 $\rightarrow 4)-O$-(3,6-di$O$-acetyl-2-deoxy-2-phthalimido- $\beta$-D-glucopyranosyl)-( $1 \rightarrow 4)$-3,6-di- $O$ acetyl-2-deoxy-2-phthalimido- $\beta$-D-glucopyranosyl azide (16): To a solution of $15(66.1 \mathrm{mg}, 52.9 \mu \mathrm{mol}, 1.00$ eq.) in dichloromethane $(1 \mathrm{~mL})$ and water $(0.05 \mathrm{~mL}), \mathrm{DDQ}(18.0 \mathrm{mg}, 79.3 \mu \mathrm{mol} 1.50$ eq. $)$ was added and stirred for $2.5 \mathrm{~h}$. Then, $\mathrm{NaHCO}_{3}$ solution was added and the crude product extracted with ethyl acetate. Afterwards the organic layer was washed with water and brine and dried over $\mathrm{Na}_{2} \mathrm{SO}_{4}$. The organic layer was evaporated to dryness followed by column chromatographic purification with the eluent mixture shown below to give compound $\mathbf{1 6}$ as a white solid (93\%).

$\boldsymbol{R}_{\mathbf{f}}=0.13$ (toluene/acetone $\left.=5: 1\right) .-{ }^{1} \mathbf{H}-\mathbf{N M R}\left(500 \mathrm{MHz}, \mathrm{CDCl}_{3}\right): \delta=7.93-$ $7.80\left(\mathrm{~m}, 4 \mathrm{H}, H_{\mathrm{Ar}}\right), 7.80-7.71\left(\mathrm{~m}, 4 \mathrm{H}, H_{\mathrm{Ar}}\right), 7.38-7.21\left(\mathrm{~m}, 5 \mathrm{H}, H_{\mathrm{Ar}}\right), 5.80-$ $5.72\left(\mathrm{~m}, 2 \mathrm{H}, 3-H, 3^{\prime}-H\right), 5.56\left(\mathrm{~d},{ }^{3} \mathrm{~J}=9.4 \mathrm{~Hz}, 1 \mathrm{H}, 1-H\right), 5.52\left(\mathrm{~d},{ }^{3} \mathrm{~J}=3.1 \mathrm{~Hz}\right.$, $\left.1 \mathrm{H}, 2^{\prime \prime}-H\right), 5.43\left(\mathrm{~d},{ }^{3} \mathrm{~J}=8.4 \mathrm{~Hz}, 1 \mathrm{H}, 1^{\prime}-H\right), 4.98\left(\mathrm{t},{ }^{3} \mathrm{~J}=9.7 \mathrm{~Hz}, 1 \mathrm{H}, 4^{\prime \prime}-H\right)$, $4.65\left(\mathrm{~d},{ }^{2} \mathrm{~J}=12.2 \mathrm{~Hz}, 1 \mathrm{H}, \mathrm{PhCH}_{\mathrm{a}} H_{b}\right), 4.51(\mathrm{~s}, 1 \mathrm{H}, 1 "-H), 4.41-4.30(\mathrm{~m}$, $\left.4 \mathrm{H}, 6-H_{b}, 66^{\prime}-H_{2}, \mathrm{PhCH}_{a} H_{\mathrm{b}}\right), 4.17$ (dd, ${ }^{3} \mathrm{~J}=10.5 \mathrm{~Hz},{ }^{3} \mathrm{~J}=8.5 \mathrm{~Hz}, 1 \mathrm{H}, 2^{\prime}-H$ ), $4.06\left(\mathrm{t},{ }^{3} \mathrm{~J}=9.9 \mathrm{~Hz}, 1 \mathrm{H}, 2-H\right), 3.98-3.93(\mathrm{~m}, 1 \mathrm{H}, 4-H), 3.90-3.85(\mathrm{~m}, 1 \mathrm{H}$, 4'-H), 3.82-3.70 (m, 3 H, 5-H, 6- $\left.H_{a}, 5^{\prime}-H\right), 3.54\left(\mathrm{dd},{ }^{3} J=9.7 \mathrm{~Hz},{ }^{3} J=3.3 \mathrm{~Hz}\right.$, $1 \mathrm{H}, 3 "-H)$, 3.67-3.58 (m, $\left.2 \mathrm{H}, 6 "-H_{2}\right), 3.28-3.23(\mathrm{~m}, 1 \mathrm{H}, 5 "-H), 2.50$ (bs, $1 \mathrm{H}, \mathrm{OH}), 2.14\left(\mathrm{~s}, 3 \mathrm{H}, \mathrm{CH}_{3} \mathrm{CO}\right.$ ), $2.11\left(\mathrm{~s}, 3 \mathrm{H}, \mathrm{CH}_{3} \mathrm{CO}\right), 2.03(\mathrm{~s}, 3 \mathrm{H}$, $\mathrm{CH}_{3} \mathrm{CO}$ ), 1.96 (s, $3 \mathrm{H}, \mathrm{CH}_{3} \mathrm{CO}$ ), 1.92 (s, $3 \mathrm{H}, \mathrm{CH}_{3} \mathrm{CO}$ ), 1.89 (s, $3 \mathrm{H}$, $\left.\mathrm{CH}_{3} \mathrm{CO}\right)$ ppm. $-{ }^{13} \mathrm{C}-\mathrm{NMR}\left(125 \mathrm{MHz}, \mathrm{CDCl}_{3}\right): \delta=170.7(\mathrm{C}, 3 \times \mathrm{CO}), 170.6$ $\left(\mathrm{C}_{\mathrm{q}}, \mathrm{CO}\right), 170.3\left(\mathrm{C}_{\mathrm{q}}, \mathrm{CO}\right), 169.9\left(\mathrm{C}_{\mathrm{q}}, \mathrm{CO}\right), 167.9\left(\mathrm{C}_{\mathrm{q}}, \mathrm{CO}\right), 137.4\left(\mathrm{C}_{\mathrm{q}}, \mathrm{C}_{\mathrm{Ar}}\right)$, $134.7\left(+, \mathrm{CH}_{\mathrm{Ar}}\right), 131.3\left(\mathrm{C}_{\mathrm{q}}, \mathrm{C}_{\mathrm{Ar}}\right), 128.0\left(+, \mathrm{CH}_{\mathrm{Ar}}\right), 128.1\left(+, \mathrm{CH}_{\mathrm{Ar}}\right), 128.6(+$, $\left.\mathrm{CH}_{\mathrm{Ar}}\right), 124.0\left(+, \mathrm{CH}_{\mathrm{Ar}}\right), 98.0\left(+, C-1^{\prime \prime}\right), 97.3\left(+, C-1^{\prime}\right), 85.5(+, C-1), 76.3(+$, C-3"), $75.0\left(+, C-4^{\prime}\right), 75.3(+, C-4), 75.4(+, C-5 "), 74.6(+, C-5), 72.8(+$, $\left.C_{-5}^{\prime}\right), 71.2\left(-, \mathrm{PhCH}_{2}\right), 70.2\left(+, C-3^{\prime}\right), 70.5(+, C-3), 67.2\left(+, C-2^{\prime \prime}\right), 67.8(+$ C-4"), $62.5\left(-, C-6^{\prime}\right), 61.9(-, C-6), 61.8\left(-, C-6{ }^{\prime \prime}\right), 55.0\left(+, C-2^{\prime}\right), 54.6(+$ $\mathrm{C}-2), 21.0\left(+, \mathrm{CH}_{3} \mathrm{CO}\right), 21.0\left(+, \mathrm{CH}_{3} \mathrm{CO}\right), 20.6\left(+, \mathrm{CH}_{3} \mathrm{CO}\right), 20.7(+$ $\left.\mathrm{CH}_{3} \mathrm{CO}\right), 20.8\left(+, \mathrm{CH}_{3} \mathrm{CO}\right), 20.9\left(+, \mathrm{CH}_{3} \mathrm{CO}\right)$ ppm. - IR (ATR): $\tilde{v}=2923$ $(\mathrm{vw}), 2118(\mathrm{w}), 1741(\mathrm{~m}), 1714(\mathrm{~m}), 1367(\mathrm{~m}), 1218(\mathrm{~m}), 1030(\mathrm{~m}), 972(\mathrm{w})$, $874(\mathrm{w}), 795(\mathrm{vw}), 720(\mathrm{~m}), 644(\mathrm{w}), 601(\mathrm{w}), 530(\mathrm{w}), 480(\mathrm{vw}) \mathrm{cm}^{-1}$. - MS $(\mathrm{ESI}): \mathrm{m} / \mathrm{z}(\%): 1152(100)[\mathrm{M}+\mathrm{Na}]^{+}, 1168(75)[\mathrm{M}+\mathrm{K}]^{+}$.

O-(2,4-Di-O-acetyl- $\beta$-D-mannopyranosyl)-(1 $\rightarrow 4)-O$-(3,6-di-O-acetyl-2deoxy-2-phthalimido- $\beta$-D-glucopyranosyl)-(1 $\rightarrow 4)-3,6$-di-O-acetyl-2deoxy-2-phthalimido- $\beta$-D-glucopyranosyl azide (17): To a solution of 16 $(239 \mathrm{mg}, 0.211 \mathrm{mmol}, 1.00$ eq.) in ethyl acetate $(4.2 \mathrm{~mL})$, a solution of $\mathrm{NaBrO}_{3}$ (106 mg, $0.634 \mathrm{mmol}, 3.00$ eq.) in water $(2.1 \mathrm{~mL})$ was added. Afterwards a solution of $\mathrm{Na}_{2} \mathrm{~S}_{2} \mathrm{O}_{5}(130 \mathrm{mg}, 0.634 \mathrm{mmol}, 3.00$ eq. $)$ in water $(4.2 \mathrm{~mL})$ was added under vigorous stirring and was stirred for another $9 \mathrm{~h}$ at room temperature after the addition was completed. The reaction mixture was diluted with ethyl acetate, separated, washed with $\mathrm{Na}_{2} \mathrm{~S}_{2} \mathrm{O}_{3}$ solution and the organic layer was dried over $\mathrm{Na}_{2} \mathrm{SO}_{4}$. Finally, the organic 
layer was evaporated to dryness followed by column chromatographic purification with the eluent mixture ratio stated below to give compound $\mathbf{1 7}$ as a white solid (58\%).

$\boldsymbol{R}_{\mathfrak{f}}=0.19$ (toluene/acetone $\left.=3: 1\right) .-{ }^{1} \mathbf{H}-\mathbf{N M R}\left(500 \mathrm{MHz}, \mathrm{CDCl}_{3}\right): \delta=7.88$ $7.82\left(\mathrm{~m}, 4 \mathrm{H}, H_{\mathrm{Ar}}\right), 7.79-7.72\left(\mathrm{~m}, 4 \mathrm{H}, H_{\mathrm{Ar}}\right), 5.79-5.72\left(\mathrm{~m}, 2 \mathrm{H}, 3-\mathrm{H}, 3^{\prime}-H\right)$, $5.56\left(\mathrm{~d},{ }^{3} \mathrm{~J}=9.4 \mathrm{~Hz}, 1 \mathrm{H}, 1-H\right), 5.41\left(\mathrm{~d},{ }^{3} \mathrm{~J}=8.3 \mathrm{~Hz}, 1 \mathrm{H}, 1^{\prime}-H\right), 5.33\left(\mathrm{~d},{ }^{3} \mathrm{~J}\right.$ $=3.1 \mathrm{~Hz}, 1 \mathrm{H}, 2 "-H), 4.90\left(\mathrm{t},{ }^{3} \mathrm{~J}=9.7 \mathrm{~Hz}, 1 \mathrm{H}, 4 "-H\right), 4.59(\mathrm{~s}, 1 \mathrm{H}, 1$ "- $H$ ), 4.39-4.32 (m, 3 H, 6- $\left.H_{b}, 6{ }^{\prime}-H_{2}\right), 4.17\left(\mathrm{dd},{ }^{3} J=10.6 \mathrm{~Hz},{ }^{3} \mathrm{~J}=8.4 \mathrm{~Hz}, 1 \mathrm{H}\right.$ $\left.2^{\prime}-H\right), 4.06\left(\mathrm{dd},{ }^{3} \mathrm{~J}=10.2 \mathrm{~Hz},{ }^{3} \mathrm{~J}=9.6 \mathrm{~Hz}, 1 \mathrm{H}, 2-H\right), 3.93-3.97(\mathrm{~m}, 1 \mathrm{H}, 4$ $H$ ), 3.86-3.90 (m, $\left.1 \mathrm{H}, 4^{\prime}-H\right), 3.60\left(\mathrm{dd},{ }^{2} \mathrm{~J}=12.0 \mathrm{~Hz},{ }^{3} \mathrm{~J}=4.9 \mathrm{~Hz}, 1 \mathrm{H}, 6 "\right.$ $\left.H_{a}\right)$, 3.843.68 (m, $\left.5 \mathrm{H}, 5-H, 6-H_{a}, 5 '-H, 3 "-H, 6 "-H_{b}\right), 3.36-3.32(\mathrm{~m}, 1 \mathrm{H}, 5 "-$ H), 2.46 (bs, $1 \mathrm{H}, \mathrm{OH}), 2.41$ (bs, $1 \mathrm{H}, \mathrm{OH}$ ), 2.14 (s, $3 \mathrm{H}, \mathrm{CH}_{3} \mathrm{CO}$ ), 2.13 (s, $3 \mathrm{H}, \mathrm{CH}_{3} \mathrm{CO}$ ), 2.11 (s, $3 \mathrm{H}, \mathrm{CH}_{3} \mathrm{CO}$ ), 1.98 (s, $3 \mathrm{H}, \mathrm{CH}_{3} \mathrm{CO}$ ), 1.91 (s, $3 \mathrm{H}$, $\mathrm{CH}_{3} \mathrm{CO}$ ), 1.88 (s, $3 \mathrm{H}, \mathrm{CH}_{3} \mathrm{CO}$ ) ppm. - ${ }^{13} \mathrm{C}-\mathrm{NMR}\left(125 \mathrm{MHz}, \mathrm{CDCl}_{3}\right): \delta=$ $171.6\left(\mathrm{C}_{\mathrm{q}}, C O\right), 170.9\left(\mathrm{C}_{\mathrm{q}}, \mathrm{CO}\right), 170.8\left(\mathrm{C}_{\mathrm{q}}, \mathrm{CO}\right), 170.5\left(\mathrm{C}_{\mathrm{q}}, \mathrm{CO}\right), 170.3\left(\mathrm{C}_{\mathrm{q}}\right.$ CO), $169.9\left(\mathrm{C}_{\mathrm{q}}, \mathrm{CO}\right), 167.9\left(\mathrm{C}_{\mathrm{q}}, \mathrm{CO}\right), 167.4\left(\mathrm{C}_{\mathrm{q}}, \mathrm{CO}\right), 134.7\left(+, \mathrm{CH}_{\mathrm{Ar}}\right)$, $131.3\left(\mathrm{C}_{\mathrm{q}}, C_{\mathrm{Ar}}\right), 124.0\left(+, \mathrm{CH}_{\mathrm{Ar}}\right), 97.2\left(+, C-1^{\prime}\right), 97.9(+, C-1 "), 85.5(+, C$ 1), $75.0\left(+, C-5^{\prime \prime}\right), 75.2(+, C-4), 75.4(+, C-4 '), 74.6(+, C H), 72.8(+, C H)$, 70.2 (+, C-3'), $70.4(+, C-3), 70.8$ (+, C-4"), 70.9 (+, CH), $69.6\left(+, C-4^{\prime \prime}\right)$, $62.6\left(-, C-6^{\prime}\right), 61.9(-, C-6), 61.7\left(-, C-6^{\prime \prime}\right), 55.0\left(+, C-2^{\prime}\right), 54.6(+, C-2)$ 21.0 (+, $\mathrm{CH}_{3} \mathrm{CO}$ ), 21.0 (+, $\left.\mathrm{CH}_{3} \mathrm{CO}\right), 20.6$ (+, $\left.\mathrm{CH}_{3} \mathrm{CO}\right), 20.7$ (+, $\left.\mathrm{CH}_{3} \mathrm{CO}\right)$, $20.8\left(+, \mathrm{CH}_{3} \mathrm{CO}\right), 20.9\left(+, \mathrm{CH}_{3} \mathrm{CO}\right)$ ppm. - IR (ATR): $\tilde{v}=2912(\mathrm{w}), 2852$ (vw), $2118(w), 1740(w), 1713(\mathrm{~m}), 1368(\mathrm{w}), 1218(\mathrm{~m}), 1033(\mathrm{~m}), 972(\mathrm{w})$, $873(\mathrm{w}), 795(\mathrm{vw}), 720(\mathrm{~m}), 644(\mathrm{vw}), 600(\mathrm{vw}), 566(\mathrm{vw}), 530(\mathrm{w}), 454$ (vw) $\mathrm{cm}^{-1}$. - MS (ESI): $\mathrm{m} / \mathrm{z}(\%): 1062(100)[\mathrm{M}+\mathrm{Na}]^{+}$.

\section{Ethyl 2,4-di-O-benzyl-3,6-di-O-(2,3,4,6-tetra-O-acetyl-D-} mannopyranosyl- $\alpha-(1 \rightarrow 2)-3,4,6$-tri-O-benzyl- $\alpha$-D-mannopyranosyl)-1thio- $\boldsymbol{\beta}$-D-mannopyranoside (28): A solution mixture of acceptor 27 (54.9 mg, $0.140 \mathrm{mmol}, 1.00$ eq.) and donor 22 (314 mg, $0.340 \mathrm{mmol}$, 2.50 eq.) in dichloromethane $(15 \mathrm{~mL})$ together with molecular sieve (20 mg MS $4 \AA$ ) were stirred for $15 \mathrm{~min}$ at room temperature. Afterwards the solution mixture was cooled down to $0^{\circ} \mathrm{C}$ and TMSOTf $(6.00 \mu \mathrm{L}$, $0.0300 \mathrm{mmol}, 0.100$ eq.) was added. The mixture was stirred at $0{ }^{\circ} \mathrm{C}$ for $3.5 \mathrm{~h}$ and afterwards neutralized with a drop of $\mathrm{NEt}_{3}$ and filtered through a plug of Celite. The solution was evaporated to dryness followed by column chromatographic purification with the eluent mixing ratio shown below to obtain 28 as colorless oil (49\%).

$\boldsymbol{R}_{\mathbf{f}}=0.40$ (cyclohexane/ethyl acetate 1:1). $-{ }^{1} \mathbf{H}-\mathbf{N M R}\left(600 \mathrm{MHz}, \mathrm{CD}_{2} \mathrm{Cl}_{2}\right)$ : $\delta=7.38-7.22\left(\mathrm{~m}, 40 \mathrm{H}, H_{\text {arom }}\right), 5.42-5.35\left(\mathrm{~m}, 4 \mathrm{H}, 1_{\mathrm{l}}-\mathrm{H}, 2 \mathrm{vv}-\mathrm{H}, 3 \mathrm{lv}-\mathrm{H}, 3 \mathrm{v}-\right.$ H), 5.28-5.19 (m, 3 H, $\left.1_{\| I}-H, 4_{\mathrm{Iv}}-H, 4 \mathrm{v}-H\right), 5.02\left(\mathrm{~s}, 1 \mathrm{H}, 1_{\mathrm{III}}-H\right), 4.99(\mathrm{~s}, 1 \mathrm{H}$, $1 \mathrm{v}-\mathrm{H}), 4.90-4.87\left(\mathrm{~m}, 2 \mathrm{H}, \mathrm{CH}_{2} \mathrm{Ph}\right), 4.76\left(\mathrm{~s}, 1 \mathrm{H}, 1_{\mathrm{Iv}}-\mathrm{H}\right), 4.73-4.47(\mathrm{~m}, 14 \mathrm{H}$,

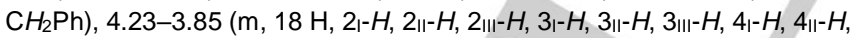
$4 ı-H, 5 ı-H, 5 ı-H, 5 ı v-H, 5 v-H, 6 ı-H, 6 ı v-H, 6 v-H), 3.75-3.61(\mathrm{~m}, 6 \mathrm{H}, 5 \mathrm{II}-H$,

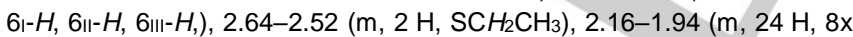
$\left.\mathrm{OCH}_{3}\right), 1.59$ (s, $\left.3 \mathrm{H}, \mathrm{SCH}_{2} \mathrm{CH}_{3}\right)$ ppm. $-{ }^{13} \mathrm{C}-\mathrm{NMR}$ (150 MHz, DMSO): $\delta=$ 170.4-169.5 ( $\left.\mathrm{C}_{q}, \mathrm{COCH}_{3}\right), 138.5\left(\mathrm{C}_{\mathrm{q}} \mathrm{OBn}\right), 128.3-127.6(\mathrm{CH}, \mathrm{OBn}), 101.1$ $\left(\mathrm{CH}, \mathrm{C}-1_{\Perp}\right), 99.2\left(\mathrm{CH}, \mathrm{C}-1_{\mathrm{IV}}\right), 99.2(\mathrm{CH}, \mathrm{C}-1 \mathrm{v}), 98.8\left(\mathrm{CH}, \mathrm{C}-1_{\mathrm{III}}\right), 81.1(\mathrm{CH}$, C-3ı), $80.8\left(\mathrm{CH}, \mathrm{C}-1_{\mathrm{I}}\right), 79.6(\mathrm{CH}, \mathrm{C}-2 \mathrm{I}), 79.3\left(\mathrm{CH}, \mathrm{C}-3_{І \prime}\right), 79.1\left(\mathrm{CH}, \mathrm{C}-3_{\text {III }}\right)$, $77.1(\mathrm{CH}, \mathrm{C}-2 ॥), 75.8(\mathrm{CH}, \mathrm{C}-2 ॥ 11), 74.9(\mathrm{CH}, \mathrm{C}-4 ॥, \mathrm{C}-4 \mathrm{I}), 74.6(\mathrm{CH}, \mathrm{C}-4 ॥$ ), $74.9\left(\mathrm{CH}_{2}, \mathrm{CH}_{2} \mathrm{Ph}\right), 73.2\left(\mathrm{CH}_{2}, \mathrm{CH}_{2} \mathrm{Ph}\right), 73.1\left(\mathrm{CH}_{2}, \mathrm{CH}_{2} \mathrm{Ph}\right), 72.9\left(\mathrm{CH}_{2}\right.$, $\left.\mathrm{CH}_{2} \mathrm{Ph}\right), 72.6(\mathrm{CH}, \mathrm{C}-5 \mathrm{l}), 72.3\left(\mathrm{CH}_{2}, 2 \times \mathrm{CH}_{2} \mathrm{Ph}\right), 71.6\left(\mathrm{CH}_{2}, 2 \times \mathrm{CH}_{2} \mathrm{Ph}\right)$, 71.7 ( $\mathrm{CH}, \mathrm{C}-5 ॥$ II), $71.5(\mathrm{CH}, \mathrm{C}-5 ॥), 69.7\left(\mathrm{CH}_{2}, \mathrm{C}-6 ॥\right), 69.5(\mathrm{CH}, \mathrm{C}-2 \mathrm{IV}, \mathrm{C}-2 \mathrm{v})$, 69.1 ( CH, C-3ıv, C-3v), $69.0(\mathrm{CH}, \mathrm{C}-5 \mathrm{Iv}, \mathrm{C}-5 \mathrm{v}), 68.8\left(\mathrm{CH}_{2}, \mathrm{C}-6\right.$ III), $66.5\left(\mathrm{CH}_{2}\right.$, C-6ı), $66.0\left(\mathrm{CH}, \mathrm{C}-4\right.$ Iv, C-4v), $62.8\left(\mathrm{CH}_{2}, \mathrm{C}-6 \mathrm{Iv}\right), 62.5\left(\mathrm{CH}_{2}, \mathrm{C}-6 \mathrm{v}\right), 26.9(\mathrm{CH}$, $\left.\mathrm{SCH}_{2} \mathrm{CH}_{3}\right), 25.3\left(\mathrm{CH}, \mathrm{SCH}_{2} \mathrm{CH}_{3}\right), 20.5\left(8 \times \mathrm{CH}_{3}, \mathrm{OAc}\right)$ ppm. - MS (MALDITOF, Matrix: DHB:CHCA $1: 1), m / z=1951[\mathrm{M}+\mathrm{Na}]^{+}$.

2,4-Di-O-benzyl-3,6-di-O-(2,3,4,6-tetra-O-acetyl- $\alpha$-D-mannopyranosyl$(1 \rightarrow 2)-3,4,6$-tri-O-benzyl- $\alpha$-D-mannopyranosyl)-mannopyranosyl$(1 \rightarrow 6)-(2,4-d i-O$-acetyl- $\beta$-D-mannopyranosyl)-(1 $\rightarrow 4)-(3,6-d i-O$-acetyl2-deoxy-2-phthalimido- $\beta$-D-glucopyranosyl)-(1 $\rightarrow 4)-3,6-d i-O$-acetyl-2- deoxy-2-phthalimido- $\beta$-D-glucopyranosyl azide (1): A solution of 28 (106 mg, $0.0549 \mathrm{mmol}, 2.40$ eq.) and 17 (23.8 mg, $0.0229 \mathrm{mmol}, 1.00 \mathrm{eq}$.) in dichloromethane $(5.00 \mathrm{~mL}$, MS $4 \AA$ ) was stirred for $1 \mathrm{~h}$ at room temperature. Then, the mixture was cooled down to $-40^{\circ} \mathrm{C}$ and NIS $(29.6 \mathrm{mg}, 0.132 \mathrm{mmol}, 2.40$ eq.) and afterwards TMSOTf $(0.500 \mu \mathrm{L}$, $0.610 \mu \mathrm{g}, 0.003 \mathrm{mmol}, 0.0500 \mathrm{eq}$.) were added. The reaction mixture was stirred for $3 \mathrm{~h}$, then it was diluted with ethyl acetate and filtered through a plug of Celite. Afterwards, the organic layers were washed with $\mathrm{NaHSO}_{3}-$ solution and brine, dried over $\mathrm{Na}_{2} \mathrm{SO}_{4}$ and evaporated to dryness followed by column chromatographic purification using the eluent mixture ratio stated below to give the octameric glycan $1(40 \%)$.

$\boldsymbol{R}_{\boldsymbol{f}}=0.42$ (cyclohexane/ethyl acetate 2:1). - MS (MALDI-TOF, Matrix: DHB:CHCA 1:1), $m / z=2908[\mathrm{M}+\mathrm{H}]^{+}$.

For more information concerning the characterization and working procedures please refer to the supporting information.

\section{Acknowledgements}

We thank the Karlsruhe School of Optics \& Photonics (KSOP), the BW Stiftung and the GRK2039 for financial support. B.L. and M.R.M.K. thank the Fonds der Chemischen Industrie, the Deutsche Forschungsgemeinschaft (instrumentation facility Pro²NMR, FOR 2290), and the HGF programme BIFTM.

\section{Keywords: Azido-Glycan • N-glycans • High-Mannose Motif •} heterogeneous/ homogeneous glycoforms $\cdot$ Oligosaccharide Synthesis Strategies • glycoproteins • strain-promoted alkyneazide cycloaddition (SPAAC) ligation • Glycomodification of Proteins •

[1] a) R. A. Dwek, Chem. Rev. 1996, 96, 683-720; b) A. Varki, R. D. Cummings, J. D. Esko, P. Stanley, G. Hart, M. Aebi, A. Darvill, T. Kinoshita, N. H. Packer, J. J. Prestegard, R. L. Schnaar, P. H. Seeberger, Essentials of Glycobiology, 3rd ed., Cold Spring Harbor Laboratory Press, Cold Spring Harbor (NY), 2015

[2] H.-J. Gabius, H.-C. Siebert, S. Andre, J. Jimenez-Barbero, H. Ruediger, ChemBioChem 2004, 5, 740-764.

[3] M. Aebi, R. Bernasconi, S. Clerc, M. Molinari, Trends Biochem. Sci. 2010, 35, 74-82.

[4] a) N. L. B. Pohl, Nat. Chem. Biol. 2009, 5, 373; b) J. Roth, Chem. Rev. 2002, 102, 285-303

[5] a) J. J. Gridley, H. M. I. Osborn, J. Chem. Soc., Perkin Trans. 1 2000, 1471-1491; b) J. Roth, Chem. Rev. 2002, 102, 285-304; c) A. Helenius, M. Aebi, Annu. Rev. Biochem. 2004, 73, 1019-1049; d) M. Aebi, R. Bernasconi, S. Clerc, M. Molinari, Trends Biochem. Sci. 2010, 35, 74-82.

[6] K. W. Moremen, M. Tiemeyer, A. V. Nairn, Nat. Rev. Mol. Cell Biol. 2012, 13, 448-462.

[7] H. Mrazek, L. Weignerova, P. Bojarova, P. Novak, O. Vanek, K. Bezouska, Biotechnol. Adv. 2013, 31, 17-37.

[8] a) R. Jefferis, J. Immunol. Res. 2016, 5358272/5358271$5358272 / 5358215$; b) S. Defaus, P. Gupta, D. Andreu, R. GutierrezGallego, Analyst 2014, 139, 2944-2967; c) R. L. Shields, J. Lai, R. Keck, L. Y. O'Connell, K. Hong, Y. G. Meng, S. H. A. Weikert, L. G. Presta, J. Biol. Chem. 2002, 277, 26733-26740; d) R. Jefferis, Nat. Rev. Drug Discovery 2009, 8, 226-234; e) R. Jefferis, Trends Pharmacol. Sci. 2009, 30, 356-362.

[9] a) R. J. Williams, Curr. Biol. 1994, 4, 942-944; b) D. Sari, K. Gupta, G. R. D. B. Thimiri, A. Aubert, P. Drncova, F. Garzoni, I. Berger, D. Sari, K. 
Gupta, G. R. D. B. Thimiri, A. Aubert, P. Drncova, F. Garzoni, I. Berger, D. Fitzgerald, I. Berger, Adv.Exp. Med. Biol. 2016, 896, 199-215; c) A. R Fersht, Proc. R. Soc. London, B 1981, 212, 351-379; d) J. M. Irache, H. H. Salman, C. Gamazo, S. Espuelas, Expert Opin. Drug Deliv. 2008, 5 703-724; e) L. Davis, J. W. Chin, Nat. Rev. Mol. Cell Biol. 2012, 13, 168182; f) E. Lattova, D. Bartusik, V. Spicer, J. Jellusova, H. Perreault, B. Tomanek, Mol. Cell. Proteomics 2011, 10, M111.007765; g) M. L. A. de Leoz, L. J. T. Young, H. J. An, S. R. Kronewitter, J. Kim, S. Miyamoto, A. D. Borowsky, H. K. Chew, C. B. Lebrilla, Mol. Cell. Proteomics 2011, 10, 1-9; h) C. Ferrara, S. Grau, C. Jager, P. Sondermann, P. Brunker, I. Waldhauer, M. Hennig, A. Ruf, A. C. Rufer, M. Stihle, P. Umana, J. Benz, Proc. Natl. Acad. Sci. U. S. A. 2011, 108, 12669-12674, S12669/12661S12669/12666; i) C. Ferrara, P. Brunker, T. Suter, S. Moser, U. Puntener, P. Umana, Biotechnol. Bioeng. 2006, 93, 851-861.

[10] L. Kalmar, K. Agoston, Z. Szurmai, B. Doenczo, J. Kerekgyarto, J. Carbohydr. Chem. 2012, 31, 203-219.

[11] a) M. A. Walczak, S. J. Danishefsky, J. Am. Chem. Soc. 2012, 134, 16430-16433; b) M. A. Walczak, J. Hayashida, S. J. Danishefsky, J. Am. Chem. Soc. 2013, 135, 4700-4703; c) B. Aussedat, B. Fasching, E. Johnston, N. Sane, P. Nagorny, S. J. Danishefsky, J. Am. Chem. Soc. 2012, 134, 3532-3541.

[12] a) M. Nagasaki, Y. Manabe, N. Minamoto, K. Tanaka, A. Silipo, A. Molinaro, K. Fukase, J. Org. Chem. 2016, 81, 10600-10616; b) I. Matsuo, M. Wada, S. Manabe, Y. Yamaguchi, K. Otake, K. Kato, Y. Ito, J. Am. Chem. Soc. 2003, 125, 3402-3403.

[13] a) C. Unverzagt, G. Gundel, S. Eller, R. Schuberth, J. Seifert, H. Weiss, M. Niemietz, M. Pischl, C. Raps, Chem. Eur. J. 2009, 15, 12292-12302 b) D. Ott, J. Seifert, I. Prahl, M. Niemietz, J. Hoffman, J. Guder, M. Moennich, C. Unverzagt, Eur. J. Org. Chem. 2012, 2012, 5054-5068, S5054/5051-S5054/5012; c) M. Moennich, S. Eller, T. Karagiannis, L. Perkams, T. Luber, D. Ott, M. Niemietz, J. Hoffman, J. Walcher, L. Berger M. Pischl, M. Weishaupt, C. Wirkner, R. G. Lichtenstein, C. Unverzagt, Angew. Chem., Int. Ed. 2016, 55, 10487-10492.

[14] a) K. Fujikawa, A. Koizumi, M. Hachisu, A. Seko, Y. Takeda, Y. Ito, Chem. Eur. J. 2015, 21, 3224-3233; b) S. Dedola, M. Izumi, Y. Makimura, Y. Ito Y. Kajihara, Biopolymers 2016, 106, 446-452.

[15] a) S. S. Shivatare, S.-H. Chang, T.-I. Tsai, C.-T. Ren, H.-Y. Chuang, L. Hsu, C.-W. Lin, S.-T. Li, C.-Y. Wu, C.-H. Wong, J. Am. Chem. Soc. 2013 135, 15382-15391; b) S. S. Shivatare, S.-H. Chang, T.-I. Tsai, S. Y. Tseng, V. S. Shivatare, Y.-S. Lin, Y.-Y. Cheng, C.-T. Ren, C.-C. D. Lee, S. Pawar, C.-S. Tsai, H.-W. Shih, Y.-F. Zeng, C.-H. Liang, P. D. Kwong, D. R. Burton, C.-Y. Wu, C.-H. Wong, Nat. Chem. 2016, 8, 338-346.

[16] a) Z. Wang, Z. S. Chinoy, S. G. Ambre, W. Peng, R. McBride, R. P. de Vries, J. Glushka, J. C. Paulson, G.-J. Boons, Science 2013, 341, 379383; b) T. Li, M. Huang, L. Liu, S. Wang, K. W. Moremen, G.-J. Boons, Chem. Eur. J. 2016, 22, 18742-18746; c) I. A. Gagarinov, T. Li, J. S. Torano, T. Caval, A. D. Srivastava, J. A. W. Kruijtzer, A. J. R. Heck, G.J. Boons, J. Am. Chem. Soc. 2017, 139, 1011-1018.

[17] L. Kroeck, D. Esposito, B. Castagner, C.-C. Wang, P. Bindschaedler, P. H. Seeberger, Chem. Sci. 2012, 3, 1617-1622.

[18] K. Lang, J. W. Chin, Chem. Rev. 2014, 114, 4764-4806.
[19] a) S. E. Soliman, P. Kovac, J. Org. Chem. 2015, 80, 4851-4860; b) D. J. Lee, S.-H. Yang, G. M. Williams, M. A. Brimble, J. Org. Chem. 2012, 77, 7564-7571; c) J. D'Onofrio, M. De Champdore, L. De Napoli, D. Montesarchio, G. Di Fabio, Bioconjugate Chem. 2005, 16, 1299-1309; d) T. Tanaka, H. Nagai, M. Noguchi, A. Kobayashi, S.-i. Shoda, Chem. Commun. 2009, 3378-3379; e) D. Lim, M. A. Brimble, R. Kowalczyk, A. J. A. Watson, A. J. Fairbanks, Angew. Chem. 2014, 53, 11907-11911.

[20] C. Koehler, P. F. Sauter, M. Wawryszyn, G. E. Girona, K. Gupta, J. J. M. Landry, M. H.-Y. Fritz, K. Radic, J.-E. Hoffmann, Z. A. Chen, J. Zou, P. S. Tan, B. Galik, S. Junttila, P. Stolt-Bergner, G. Pruneri, A. Gyenesei, C. Schultz, M. B. Biskup, H. Besir, V. Benes, J. Rappsilber, M. Jechlinger, J. O. Korbel, I. Berger, S. Braese, E. A. Lemke, Nat. Methods 2016, 13, 997-1000.

[21] C. Unverzagt, H. Kunz, J. Prakt. Chem./Chem.-Ztg. 1992, 334, 570-578.

[22] R. S. McGavin, R. A. Gagne, M. C. Chervenak, D. R. Bundle, Org. Biomol. Chem. 2005, 3, 2723-2732.

[23] T. Mukaiyama, K. Takeuchi, H. Jona, H. Maeshima, T. Saitoh, Helv. Chim. Acta 2000, 83, 1901-1918.

[24] a) P. Soderman, E. A. Larsson, G. Widmalm, Eur. J. Org. Chem. 2002, 1614-1618; b) J. Tatai, P. Fuegedi, Org. Lett. 2007, 9, 4647-4650.

[25] a) R. W. Binkley, M. G. Ambrose, D. G. Hehemann, J. Carbohydr. Chem. 1987, 6, 203-219; b) K. Bock, C. Pedersen, J. Chem. Soc., Perkin Trans. 21974, 293-297.

[26] S. Wolfe, B. M. Pinto, V. Varma, R. Y. N. Leung, Can. J. Chem. 1990, 68, 1051-1062.

[27] M. Niemietz, L. Perkams, J. Hoffman, S. Eller, C. Unverzagt, Chem. Commun. 2011, 47, 10485-10487.

[28] a) S. Valerio, A. ladonisi, M. Adinolfi, A. Ravida, J. Org. Chem. 2007, 72 , 6097-6106; b) L. Chen, Z. Tan, Tetrahedron Lett. 2013, 54, 2190-2193; c) L. N. Mueller, C. Muhle-Goll, M. B. Biskup, Org. Biomol. Chem. 2010 , 8, 3294-3299; d) T. Baba, K. Watanabe, N. Yonezawa, M. Hiroto, Y. Arai, Carbohydr. Res. 1988, 177, 163-172; e) B. M. Swarts, Z. Guo, Chem. Sci. 2011, 2, 342-2352.

[29] a) T. J. Boltje, J.-H. Kim, J. Park, G.-J. Boons, Org. Lett. 2011, 13, 284287 ; b) C. M. Pedersen, L. U. Nordstrom, M. Bols, J. Am. Chem. Soc 2007, 129, 9222-9235.

[30] P. Carcabal, I. Huenig, D. P. Gamblin, B. Liu, R. A. Jockusch, R. T. Kroemer, L. C. Snoek, A. J. Fairbanks, B. G. Davis, J. P. Simons, J. Am. Chem. Soc. 2006, 128, 1976-1981.

[31] C.-R. Shie, Z.-H. Tzeng, S. S. Kulkarni, B.-J. Uang, C.-Y. Hsu, S.-C. Hung, Angew. Chem., Int. Ed. 2005, 44, 1665-1668.

[32] a) B. Aussedat, Y. Vohra, P. K. Park, A. Fernandez-Tejada, S. M. Alam, S. M. Dennison, F. H. Jaeger, K. Anasti, S. Stewart, J. H. Blinn, H.-X. Liao, J. G. Sodroski, B. F. Haynes, S. J. Danishefsky, J. Am. Chem. Soc. 2013, 135, 13113-13120; b) F. Chiodo, P. M. Enriquez-Navas, J. Angulo, M. Marradi, S. Penades, Carbohydr. Res. 2015, 405, 102-109.

[33] G. E. Martin, B. D. Hilton, K. A. Blinov, J. Nat. Prod. 2011, 74, 2400-2407.

[34] T. Minuth, M. Irmak, A. Groschner, T. Lehnert, M. M. K. Boysen, Eur. J. Org. Chem. 2009, 997-1008. 